\title{
Metabolomics of disease resistance in crops
}

\section{Arbona and A. Gómez-Cadenas}

Ecofisiologia i Biotecnologia. Dept. Ciències Agràries i del Medi Natural. Universitat Jaume I. Castelló de la Plana (SPAIN).

\begin{abstract}
Plants are continuously exposed to the attack of invasive microorganisms, such as fungi or bacteria, and also viruses. To fight these attackers, plants develop different metabolic and genetic responses whose final outcome is the production of toxic compounds that kill the pathogen or deter its growth or semiotic molecules that alert other individuals of the same plant species. These molecules are derived from the secondary metabolism and their production is induced upon detection of a pathogen-associated molecular pattern (PAMP). These PAMPs are different molecules that are perceived by the host cell triggering defense responses. PAMP-elicited compounds are highly diverse and specific of every plant species and can be divided into preformed metabolites or phytoanticipins that are converted into toxic molecules upon pathogen perception, and toxic metabolites or phytoalexins that are produced only upon pathogen attack. Moreover, plant volatile emissions are also modified in response to pathogen attack to alert neighboring individuals or to make plants less attractive to pathogen vector arthropods. Plant metabolite profiling techniques have allowed the identification of novel antimicrobial molecules that are induced upon elicitation. However, more studies are required to assess the specific function of metabolites or metabolite blends on plant-microbe interactions.
\end{abstract}

\section{Introduction}

Opposite to animals, vascular plants do not possess an immune system which involves the presence of cells specialized in detection, prosecution and elimination of invasive microorganisms. However, plants are still able to respond to the attack of microorganisms and predatory arthropods relying on different mechanisms, first an innate immunity comprising a sensitive system to detect Pathogen-Associated Molecular Patterns (PAMPs) based on membrane-bound specific pattern recognition receptors (PRR) (PAMP-Triggered Immunity or PTI), and a second layer named 
Effector-Triggered Immunity or ETI, involving intracellular proteins that respond to pathogen effectors or virulence factors.

\section{PAMP-Triggered Immunity (PTI)}

PAMPs are characteristic molecular structures shared by large groups of pathogens that act as elicitors of defense responses in plants. Among PAMPs perceived by plants, fungal structures such as cell wall $\beta$-glucan, conserved epitopes from cell wall transglutaminases and elicitins (secreted lipotransfer proteins); or bacteria-derived molecules such as lipopolysaccharides, flagellin, bacterial cold-shock proteins, and EFTu are found. Perception of PAMPs is not necessarily a specific event as some of them can elicit defense responses in a wide range of plant species (e.g. flagellin or the isolated epitope flg22). Nevertheless, most specific PRRs responsible of this pattern recognition remain elusive and only a few have been so far characterized. Most plant PRRs are membrane-bound receptor-like kinases comprising a ligand-binding domain on the cell surface. These molecules can also contain a cytoplasmic kinase domain (Receptor-Like Kinases or RLKs) or not (Receptor-Like Protein types or RLPs) that initiates PRR-triggered immunity upon PAMP perception (Macho and Zipfel, 2014). For a proper immune response induction, these receptors dimerize upon perception of the PAMP. To this respect, several models showing homo-, hetero-dimerization and heteromultimerization exist. Chitin perception in Arabidopsis is mediated by LysMRLK CERK1/RLK1/LYK1. This CERK1 receptor contains three extracellular domains that bind long fungal chitin oligomers (comprising seven to eight $\mathrm{N}$-acetyl-glucosamine residues) leading to its homodimerization and formation of an active receptor complex (shorter chitin oligomers do not induce receptor homodimerization and do not trigger immune response). Upon homodimerization, CERK1 cytoplasmic kinase domains are brought together enabling intermolecular transphosphorylation, following a similar mechanism to that of animal tyrosine kinases (Macho and Zipfel, 2014). Interestingly, chitin perception in rice is mediated by a mechanism known as heteromultimerization in which a chitin binding protein CEBiP (a predicted GPI-anchored protein) with no kinase cytoplasmic domain (as an RLP). Therefore, transduction signal after chitin perception requires the cooperation with additional proteins. CEBiP homodimerizes in the presence of active chitin and also forms a hetero-oligomeric complex with OsCERK1 (an ortholog of Arabidopsis CERK1 but its only extracellular domain does not bind chitin) (Shimizu et al., 2010). Flagellin detection and signal transduction 
carried out by PRRs is well studied in the model plant Arabidopsis thaliana. In this plant species, LRR-RLK-FLS2 is the PRR responsible for binding flagellin from flagellated phytopathogenic procariotes (such as Pseudomonas syringae or Xanthomonas spp.) or the 22-aminoacid epitope flg22 (Dardick et al., 2012). This is a Leucine Repeat-Rich RLK that forms heterodimers with LRR RLK-BAK1/SERK3 regulatory complex upon epitope binding. Although, dimerization of FLS2 and BAK1 is not required for a proper flg22 binding both molecules act as co-receptors for epitope binding and signal activation. A similar activation mechanism has been described for the brassinosteroid receptor BRI1 (another LRR-RLK) that binds to co-receptors BAK1 or SERK1. This interaction between LRR-RLKs (and LRR-RLP) and BAK1 or related SERK proteins seems to be a common trend as supported by increasing evidence (Macho and Zipfel, 2014). As for rice CERK1, some mechanistic differences are also found in this case as well: OsSERK2, an Oryza sativa ortholog of BAK1 binds constitutively to the LRR-RLK XA21 conferring resistance to Xanthomonas oryzae pv. oryzae, but no ligand has been confirmed yet therefore it cannot be precluded how PAMP interaction would modify OsSERK2-XA21 interaction (Bahar et al., 2014; Sun et al., 2013). A more complex interaction has been observed in tomato, where the BAK1 ortholog interacts with an LRR-RLP named Eix1 and negatively regulates signaling mediated by Eix2 (a related LRR-RLP). Upon ligand perception, receptor complexes interact with different cytoplasmic partners to trigger intracellular signaling leading to a rapid ROS burst and expression of genes involved in defense (Bar et al., 2010). One of these partners is the kinase BIK1 that has several protein targets in Arabidopsis such as AtRBOHD NADPH oxidase involved in apoplastic ROS production in response to PAMP perception. Another protein target in rice that responds to chitin-triggered signaling through OsCERK1 is the Rac GDP/GTP exchange factor (OsRacGEF1) that activates OsRac1 leading to resistance to fungal pathogens (Akamatsu et al., 2013). Moreover, the activation of defense responses on PAMP perception needs to be properly shut down after the pathogenic threat is over. To this respect, as signaling activation is driven by phosphorylation negative regulation modulated by protein phosphatases is a plausible explanation. Hence, several protein phosphatases 2C have been shown to interact with members of different PRR complexes: KAPP interacts with FLS2 (flg22-triggered responses) as well as with other plant RLKs (Gomez-Gomez, 2001), in rice XB15 phosphatase and XB24 ATPase associate with XA21 thus regulating the phosphorylation status of PRR (Park et al., 
2008). Additionally, PAMP-bound activated RLKs are also degraded to enable the restoration of free receptors at the plasma membrane. Degradation of receptors is carried out through polyubiquitination catalyzed by the E3-ubiquitin ligases PUB12 and PUB13 that constitutively interact with BAK1 and are recruited into the FLS2 receptor complex after perception of flg22 (Lu et al., 2011).

\section{Effector-Triggered Immunity (ETI)}

However, these defense responses can be inhibited by virulence factors that successful pathogens have evolved. In turn, adapted plants have also developed resistance proteins that detect these virulence factors and inhibit their action on cell targets. This response is mediated by resistance proteins ( $\mathrm{R}$ proteins, most of them encoding highly polymorphic NB-LRR proteins) that recognize these virulence factors leading to the induction of a hypersensitive response (HR) including programmed death of infected cells inhibiting pathogen spread. This is considered an enhanced PTI response that leads to disease resistance. It is worth noting that this ETI branch is effective on obligate biotrophs (microorganisms that can only feed on living cells) or hemibiotrophs but not on pathogens that kill host cells during colonization or necrotrophs (Jones and Dangl, 2006). It is hypothesized that these NB-LRR proteins act as guards of intracellular targets of pathogen effectors (this recognition can be carried out directly or indirectly by detecting products of the action on host target molecules). As mentioned above, this layer of defense leads to HR and induction of programmed cell death contributing to arrest pathogen expansion. This programmed cell death has been associated to the intracellular production of ROS by mitochondria and chloroplasts and the activation of NB-LRR and metacaspases (Coll et al., 2011).

\section{Metabolite profiling techniques in plant-pathogen interactions}

In recent years, phytopathologists have gained access to modern metabolite profiling platforms that allow monitoring hundreds of metabolites in a single analysis. Moreover, these techniques are exhaustive enough to allow researchers to identify novel metabolites with potential antimicrobial activity (Allwood et al., 2008). Hence, comparison of resistant versus susceptible varieties, genotypes or mutants is a fundamental tool to decipher resistance mechanisms and identify defense compounds. In this context, instead of monitoring a few (known toxic compounds) the array of low molecular weight metabolites (metabolome) are analyzed and quantitated constituting 
the whole metabolic phenotype of a plant. To this respect, it is then possible to identify pre- and post-invasion resistant and susceptible metabolic phenotypes and infer relationships among different pathways.

Most non-volatile secondary metabolites are semipolar chemical compounds that can be easily separated on a C18 column (or specifically modified versions of this packing) using reversed phase liquid chromatography coupled to a high resolution mass spectrometer (usually a hybrid quadrupole/time-of-flight or QTOF-MS) through an atmospheric pressure ionization source (either electrospray ESI or chemical ionization, APCI). This instrumental coupling is known as LC/MS. High resolution QTOF-MS instruments provide accurate mass measurements (less than 0.02 arbitrary mass units of difference) and real isotopic pattern (related to the particular elemental composition of each compound). In addition, these instruments also allow fragmentation of selected compounds, thanks to the presence of a quadrupole segment and a collision cell before the flight tube, to gain structural information. This configuration is usually sufficient to analyze different types of secondary metabolites: flavonoids and triterpenoids (Arbona et al., 2015; Böttcher et al., 2008), phenolics (Böttcher et al., 2009a), glucosinolates and related compounds (Böttcher et al., 2009b; Zandalinas et al., 2012), lipids (Zoeller et al., 2012), etc...Due to the high specificity of secondary metabolites and the little information available on them (mass spectra, fragmentation pattern, elution time, etc...), together with the poor cross-platform exchangeability of LC/MS data, make very often necessary their de novo identification using in-house built databases or matching the annotation (MS spectra and retention time) with pure standards. For these reasons, ensuring high quality spectral information is of key importance to facilitate mass spectra curation and interpretation (Figure 1).

Complementarily, volatiles and polar compounds are analyzed by means of gas chromatography coupled to mass spectrometry (GC/MS). Polar compounds such as carbohydrates, free aminoacids and carboxylic acids of the Krebs cycle can be analyzed by GC/MS as methoxime/trimethylsilyl derivatives (Roessner et al., 2001) whereas volatiles do not need any further processing (Beck et al., 2014). Identification of polar metabolites and volatiles in this case is carried out in a targeted fashion using publiclyavailable databases such as the Gölm Metabolite Database (http://gmd.mpimpgolm.mpg.de/), NIST or the Fiehn metabolite database (http://fiehnlab.ucdavis.edu/db). This is possible for several reasons: 1) In GC analyses, retention index markers, such as 
fatty acid methyl esters or alkanes, are added to standardize retention times of all eluted compounds to retention indices; this makes GC a more robust chromatographic technique than LC, where retention index markers are not employed; 2) the ionization in GC/MS is achieved through electron impact (EI), essentially an electron beam collides with each eluted metabolite and generates a population of ions. Retention indices (RI) as well as fragment ions are then used to match metabolite identities in metabolite databases.

Analysis of metabolomics data (both LC/MS and GC/MS) requires the aid of bioinformatic tools that allow extraction of chromatographic and spectral data in a manageable file format, such as MS Excel spreadsheets. This step can be achieved using different software tools developed so far: xcms (Smith et al., 2006), metAlign (Lommen, 2009), MzMine (Katajamaa et al., 2006; Pluskal et al., 2010) or, more recently, GridMass (Treviño et al., 2015), etc...perform peak picking and alignment of mass chromatographic peaks (Arbona et al., 2009). There are also tools for integrated GC/MS analysis that allow performing peak picking and alignment, RI calculation and matching of MS spectra in databases: TargetSearch (Cuadros-Inostroza et al., 2009), TagFinder (Luedemann et al., 2008) or FiehnLib (Strehmel et al., 2013). In addition, it is possible to annotate unknown derivatized metabolites by using GC/APCI(+)-QTOFMS. The APCI ion source generates predominantly protonated ions and very few fragments or none. Annotation of unknowns requires the evaluation of adduct ion formation and calculation of elemental composition. In addition, an estimation of the number of methoxime and trimethylsilyl units per derivatized molecule is needed followed by a deep examination of the corresponding collision-induced dissociation mass spectrum (Strehmel et al., 2013).

Analysis of volatiles does not require previous derivatization and due to the nature of the matrix detection limits can be very low. The main problem is that these compounds need to be collected in vivo from plant samples because they are released to the atmosphere as they are synthesized. There are two main collection strategies: 1) sampling the headspace of a hermetically closed vial or flask in which the plant material is contained and 2) force an inert gas in this hermetically closed flask to carry the metabolites that are collected in a special adsorbent material (a solid phase extraction technique, SPE, applied to gas matrices). The first option implies that the surrounding headspace gas of the vial is not renewed. Then, the equilibrium between the plant and 
the atmosphere is quickly reached and the migration of volatiles from plant tissues to the headspace gas is therefore reduced. In addition, although the matrix (air) is quite inert to MS detectors, emission of volatiles is often very slow and, therefore, long incubation periods are required (Figure 1). The second option is more advantageous in terms of extraction efficiency and the possibility of including a pre-concentration step. Following this strategy, gas surrounding the plant is continuously forced through a SPE cartridge and emitted volatiles retained. Cartridges are subsequently eluted with $n$ hexane and injected in the GC/MS. An improved version is the SPME, the M standing for micro, in which cartridge elution volumes are significantly reduced (Beck et al., 2014; Tikunov et al., 2005).

\section{Metabolic responses to pathogen infection}

Plants produce a vast array of low molecular weight compounds (an estimated of 100,000 different metabolites in the plant kingdom). These molecules, collectively known as secondary metabolites, are not essential for cell survival but do have a specific role in the adaptation to a changing environment. Most of them can be primarily grouped in four branches: isoprenoids, phenylpropanoids, alkaloids and fatty acid/polyketides (Dixon, 2001). Importantly, most secondary metabolites are specific of a plant family/genus or even species, making their functional characterization in plant defense by conventional molecular and genetic techniques a daunting task. Although most antimicrobial metabolites synthesized by plants have a broad spectrum activity, their relative activity relies on the presence of detoxification enzymes in a pathogen strain. The synthesis and accumulation of these compounds is induced after perception of pathogen attack (perception of PAMPs or pathogen effector molecules). Defense compounds can be divided into phytoalexins, that are produced upon pathogen perception, and phytoanticipins that are synthesized in an inactive form and pathogen recognition triggers its biochemical modification into a toxic derivative (Piasecka et al., 2015). It is important to recall that plants challenged with pathogenic fungal or bacterial strains modify their metabolome in the attacked cells (local response) and this response can be extended to the rest of the plant (systemic response). However, not all secondary molecules (synthesized de novo or modified during pathogen attack) have a toxic role, and not only one molecule is responsible for the toxic effect. Therefore, to ascertain the role of each elicited metabolite, it should be isolated and tested for toxic activity under control conditions, which is not always possible. 
In this review, we described some compounds which in vivo function in plant immunity against bacterial and fungal pathogens has been studied in detail (see Figure 2 for the most important groups of plant metabolites involved in defense).

\section{Phytoanticipins}

Saponins are glycosides from lipophilic polycyclic structures derived from the isoprenoid pathway, occurring as triterpenoids or steroids (sapogenin). These molecules are widely distributed in the plant kingdom (mainly in dicots but also in some monocots) (Huhman et al., 2005; Piasecka et al., 2015). This group includes triterpenoids from Avena spp. named avenacins (A1, A2, B1 and B2) only accumulated in roots whereas avenacosides, with steroidal sapogenins, are accumulated in leaves (Piasecka et al., 2015). In addition, steroidal glycoalkaloids found in solanaceous plant species constitute important representatives of this group (e.g. $\alpha$-tomatine of Solanum lycopersicum L. Mill). This compound is highly abundant in green tomato fruits showing values of $500 \mathrm{mg} \mathrm{kg}^{-1}$ fresh fruit weight and it is degraded as the fruit ripens (Friedman, 2002). This compound has been shown to have an important activity against fungal pathogens. Hence, expression of $\beta_{2}$-tomatinase gene from Septoria lycopersici in Nectria haematococca, a fungus that can colonize red tomato fruits but not green ripe ones, enabled it to detoxify $\alpha$-tomatine and its ability to parasitize green tomato fruits (Sandrock and VanEtten, 2001). More recently, it has been shown that mutant Cladosporium fulvum lines with suppressed CfTom1 glycosyl hydrolase activity (GH10 tomatinase) exhibited significantly lower virulence in tomato (Kmen et al., 2013). This is due to the accumulation of tomatidine upon cleavage of $\alpha$-tomatine by CfTom 1 hydrolase that suppresses induced defense responses in tomato (Ito et al., 2004). Moreover, the role of avenacins in immunity in oat has been studied by means of a genetic screening of a mutant population of Avena strigosa leading to the identification of saponin deficient (sad) mutants. These mutants are deficient in enzymes that are specifically involved in avenacin biosynthesis and not avenacosides. Therefore, roots of homozygous sad lines exhibited hyper-susceptibility to adapted and non-adapted fungal strains. (Mugford et al., 2013).

Glucosinolates are the most studied secondary metabolites. Globally, these molecules are $\beta$-D-thioglucosides- $N$-hydroxysulfates with different aliphatic, aromatic or indolic substitutions and are primarily present in Brassicales and some species of the 
Euphorbiaceae family. Glucosinolates are derived from different aminoacids such as alanine, valine/leucine, isoleucine, methionine, phenylalanine/tyrosine and tryptophan. Nevertheless, not all possible structures are present in all brassicaceae species but a particular subset. For instance, in the model species Arabidopsis thaliana, aliphatic glucosinolates derived from methionine and indolic glucosinolates derived from tryptophan are abundant (Piasecka et al., 2015); in leaves of cultivated rapeseed, levels of some aliphatic glucosinolates such as progoitrin, gluconapin and glucobrassicanapin and indolics such as neoglucobrassicin are predominant whereas in kale, cabbage (Velasco et al., 2011) and wild radish, indolic glucosinolates were less abundant compared to aliphatics (Malik et al., 2010). There is a wealth of information on the interaction of glucosinolates with the environment. In their glycosylated form, glucosinolates are quite stable and biologically inactive but the activation of $\beta$ thioglucoside hydrolases or myrosinases upon pathogen attack initiates glucosinolate hydrolysis and release of toxic breakdown products (Grubb and Abel, 2006). Breakdown products are unstable and decompose in different types of molecules including isothiocyanates (ITCs), nitriles and epithioalkanes that have the toxic effect on microbes. Particularly, ITCs derived from aliphatic glucosinolates have a deterrent activity against predating arthropods such as spider mites (Piasecka et al., 2015; Zhurov et al., 2014); those derived from indolic glucosinolates have antifeedant effects on aphids (Kim et al., 2008). In Arabidopsis thaliana, tryptophan-derived metabolites conferred non-host resistance to Plectosphaerella cucumerina. For instance, cyp79b2/cyp79b3 double mutant, that cannot convert tryptophan to the indol-3acetaldoxime the first committed step in indol glucosinolate biosynthesis, exhibited an increased $P$. cucumerina entry rate compared to wt or phytoalexin deficient 3 (pad3) mutants (Sanchez-Vallet et al., 2010). In addition, challenging Arabidopsis or other brassicaceae with pathogens induces expression of PEN2 that encodes a lysosomeassociated atypical myrosinase that metabolizes indolic glucosinolates generating particular breakdown products such as raphanusamic acid and indol-3-amine and also induces the expression of CYP81F2, a P450 cytochrome monooxygenase that catalyzes the hydroxylation of indol-3-ylmethyl glucosinolate into hydroxyindol-3-ylmethyl glucosinolate. Both loss-of-function pen2 and cyp81f2 Arabidopsis mutants exhibit similar penetration phenotypes in non-adapted fungal pathogens such as Blumeria graminis f. sp. hordei (Bednarek et al., 2009). 
Cyanogenic glucosides are hypothesized to be the precursors of glucosinolates and are widespread in the plant kingdom including ferns and gimnosperms. Chemically, these molecules are $\beta$-D-glucosides of $\alpha$-hydroxynitriles derived from tyrosine, phenylalanine, valine, leucine and isoleucine. As glucosinolates, these metabolites are quite stable and biologically inactive as synthesized, but after hydrolysis the $\alpha$ hydroxynitriles released decompose spontaneously to generate hydrogen cyanide. These metabolites are known to have an influence on plant-arthropod interaction but their role in defense against microbial pathogens is not yet clear. To this respect, highly cyanogenic Phaseolus lunatus accessions showed an elevated susceptibility to the hemibiotroph Colletotrichum gloeosporiodes compared to genotypes with a lower cyanogenic potential. These accessions also showed a significantly lower polyphenol oxidase activity; indeed, exogenous HCN application also depressed the activity of this enzyme. Likewise, highly cyanogenic varieties of Hevea brasiliensis (rubber tree) exhibited low scopoletin (a coumarin phytoalexin) accumulation and, hence, a strong susceptibility to the blight fungus Microcyclus ulei (Lieberei et al., 1989). This generalized depression of plant immunity upon hydrolysis of cyanogenic glucosides has been associated to the toxicity of HCN gas on neighboring plant cells that inhibits enzyme activity. On the contrary, in barley, cyanogenesis has proved to be beneficial against pathogenic microbes. However, accumulation of leucine-derived epìheterodendrin does not render cyanogenic barley plants since no specific $\beta$ glucosidase is expressed. Transient expression of the sorghum cyanogenic $\beta$ glucosidase dhurrinase2 in barley reduced notably its colonization by Blumeria graminis f. sp. hordei, indicating that cyanogenesis is effective against this biotrophic fungus (Lipka et al., 2005; Nielsen et al., 2006).

Benzoxazinone glucosides are another group of phytoanticipins found primarily in crops of the Poaceae family including corn (Zea mays), wheat (Triticum spp.), rye (Secale cereale) and some barley wild relatives. In corn and wheat, the main accumulating benzoxazinone glucoside is DIMBOA (2,4-dihydroxy-7-methoxy-1,4benzoxazin-3-one) glucoside. Their role in plant immunity has been assigned based on a positive correlation between their accumulation in tissues and pathogen resistance. As in cyanogenic glucosides or glucosinolates, their function is attributable to aglycones whereas glycosylated forms are stable and harmless. As aglycones, these molecules have shown a remarkable antifungal activity in vitro against a wide range of plant 
pathogens. In vivo, reverse genetics experiments also support the role of these metabolites in plant immunity. That is the case of the $b x 1$ corn, mutant unable to synthesize DIMBOA glucoside, which showed an extreme susceptibility to Septosphaeria turcica, responsible of corn leaf blight. Moreover, challenging corn plants with different pathogens not only induces accumulation and hydrolysis of DIMBOA glucosides but also its metabolism to other forms, such as the monohydroxylated and dimethoxylated HDMBOA, that can also be synthesized de novo, as demonstrated by its accumulation in bx1 plants (Ahmad et al., 2011; Huffaker et al., 2011).

\section{Phytoalexins}

As mentioned above, phytoalexins are antimicrobial compounds that are toxic per se and produced upon pathogen attack.

Camalexin is the typical phytoalexin from Arabidopsis thaliana which is synthesized from tryptophan after its metabolism to indol-3-yl acetaldoxime catalyzed by CYP79B2 and CYP79B3, being the only step shared with indole glucosinolate biosynthesis (Böttcher et al., 2009b; Glawischnig, 2007). Afterwards, indol-3-yl acetaldoxime is converted to indol-3-yl acetonitrile (IAN) by CYP71A13, constituting another limiting step. This metabolite is then conjugated to cysteine and then converted spontaneously or in a reaction catalyzed by CYP71B15 to dihydrocamalexic acid, the direct precursor of camalexin and substrate of PAD3. Camalexin accumulates upon elicitation with pathogens (Mert-Türk et al., 2003; Schlaeppi et al., 2010) but also after subjecting Arabidopsis to $\mathrm{Cd}^{2+}$ or $\mathrm{Ag}^{+}$stress (Mert-Türk et al., 2003). Although not all cruciferous plants accumulate camalexin on pathogen attack, most phytoalexins of this species are derived from tryptophan and, therefore, harbor an indole moiety. To this respect, cruciferous phytoalexins can be divided into six groups depending on the initial core structure: group I phytoalexins comprise indole-substituted compounds with thiocarbamate or dithiocarbamate and dithioimidate moieties, group II are based on cyclobrassinin sulfoxide, core structure of group III phytoalexins is indol-3ylacetonitrile whereas group IV contain indol-3-ylacetaldehyde; phytoalexins from group V are known as ‘spiro’ and contain a methyl thiodihydrothiazole group attached to the indole moiety. Finally, group VI phytoalexins, in which camalexin is included, is constituted of relatively stable compounds with different structures and MS/MS 
fragmentation patterns from those in the rest of groups (Pedras et al., 2006). As an example, rapeseed seedlings infected with Plasmodiophora brassicae produced at least six different indole phytoalexins: spirobrassinin (V), brassilexin (VI), brassicanate (IV), rutalexin (II), cyclobrassinin (II) and 4-methoxybrassinin (I) (Pedras et al., 2008). The model plant Thellungiella halophila accumulated wasalexins (I) and methoxybrassenin (has a dimethyl acetylcarbonimidodithioate substituent on the methoxyindole ring and not a methyl ethylcarbamodithioate as methoxybrassinin) upon elicitation with $\mathrm{CuCl}_{2}$ whereas camalexin could not be detected (Pedras and Adio, 2008).

In other plant species, compounds derived from distinct pathways act as phytoalexins and are produced upon pathogen elicitation: phenols, acetophenones, biphenyls and dibenzofurans, stilbenes, coumarins, flavonoids, terpenes, etc. (Gottstein and Gross, 1992). In Vitis vinifera, the stilbenoid phytoalexin resveratrol can be present alone or forming different oligomers. Moreover, this metabolite has gained scientific relevance due to its attributed health properties (Vogt, 2010). Resveratrol synthesis is catalyzed by stilbene synthase (STS) from coenzyme A esters of cinnamic acid derivatives (particularly, resveratrol derives from p-coumaroyl-CoA derivatives). This STS enzyme is encoded by a multigene family in grapevine and is phylogenetically related to chalcone synthase that competes with STS by the phenolic acid-CoA derivatives. The expression of this gene is induced by biotic or abiotic elicitors, increasing phytoalexin levels (Jeandet, 2015; Jeandet et al., 2002). Mulberry (Morus alba) also produce stilbene phytoalexins (oxyresveratrol) upon elicitation with fungal pathogens such as Fusarium solani f. sp. mori. (Gottstein and Gross, 1992).

Another group of phytoalexins widely distributed in angiosperms are coumarins and the most important representative is scopoletin. This phytoalexin was first identified in rubber tree after infection with pathogenic fungi (Gottstein and Gross, 1992). Its synthesis arises from feruloyl-CoA in a single hydroxylation step catalyzed by a dioxygenase, subsequent isomerization, rotation and lactonization. Moreover, scopoletin can be further modified by UDP-glucosyl transferases rendering scopolin (Vogt, 2010). In Citrus, irradiation and infection with pathogens also induces accumulation of several coumarin-type phytoalexins. Scoparone was isolated from the bark tissue and fruit rind of sweet orange after infection with Phytophthora citrophthora (Afek and Sztejnberg, 1988). Its accumulation was associated to resistance to $P$. citrophothora and antifungal treatments such as fosetyl-Al also increased scoparone levels in Citrus tissues (Gottstein 
and Gross, 1992). Nevertheless, some coumarins might have an opposite effect on pathogen growth. Inoculation of wounded C. limon fruits with Penicillium digitatum rendered a $2 \%$ of fruits exhibiting green mold symptoms. However, when epicarp oil from lemons was isolated and applied to washed fruit wounds, green mold development increased up to $92 \%$. Fractionation and spectrometric assays allowed identification of the coumarin prangolarin that could act as a facilitator of green mold penetration and invasion (Arimoto et al. 1995).

Flavonoids also constitute a widely distributed group of plant secondary metabolites. They are highly structurally diverse and are involved in many essential processes including defense against pathogens and protection against stress-induced damage. To this respect, there are 'preformed' flavonoids that are synthesized during the normal development of a plant, and could also be involved in pathogen defense, and also flavonoids that are synthesized on pathogen attack (Treutter, 2006). This group of compounds comprises anthocyanins (active against bacterial blight agent Xanthomonas spp. in cotton leaves), flavones, flavonols (that occur in the lesion margins after infection in Eucalyptus globulus), flavanones and dihydroflavonols (aglycones and glycosylated forms), chalcones, dihydrochalcones and aurones (Williams and Grayer, 2004). These compounds, as stilbenes and coumarins, are synthesized from $p$ coumaroyl-CoA. This compound is metabolized by chalcone synthase (CHS) into chalcone, the first precursor molecule in flavonoid biosynthesis (Vogt, 2010). The occurrence of these metabolites in several plant species as defense compounds has been extensively studied: the isoflavonoids glyceollins in soybean (Ebel et al., 1976), pisatin in pea (Perrin and Bottomley, 1961), medicarpin in alfalfa (He, 2000), etc. They are effective not only against fungal pathogens but also against bacteria (Piasecka et al., 2015). In grass species several examples of flavonois after pathogen inoculation are found: flavanone sakuranetin in rice (Hasegawa et al., 2014) or 3-deoxyanthocyanidins in sorghum (e.g. apigenindin and luteolinidin) (Snyder and Nicholson, 1990). Indeed, impairment in the synthesis of any of these metabolites was associated to enhanced susceptibility (Piasecka et al., 2015). In legumes, the most important phytoalexins are of the isoflavonoid type including medicarpin, glyceollin II, kievitone and vestitol (Harborne, 1999). In mulberry, a group of flavanoids named kuwanons including approximately 12 members were identified as antifungal metabolites. Moreover, infection of mulberry with Fusarium solani or Stigmina mori allowed the identification 
of morusin, a diphenylpropane derivative and its accumulation inhibits fungal and bacterial growth (Gottstein and Gross, 1992). Infection of sweet orange citrus fruits with $P$. citrophthora induced the accumulation polymethoxylated flavones (nobiletin, sinensetin and tangeretin) and the hydrolysis of flavanone glycosides (hesperidin and isonaringin) thus increasing aglycone levels. These compounds exhibited a significant antimicrobial activity in vitro and its induction appeared as a plausible defense mechanism in citrus (del Río et al., 2004). In addition, modulation of levels of polymethoxylated flavones in citrus fruits by hormonal treatments increased resistance to $P$. citrophthora (Ortuño et al., 2002). More recently, a sequential proteomics and metabolomics postharvest study on C. unshiu (satsuma mandarin) fruits revealed the induction of several flavonoid glycosides and aglycones after heat treatment, resulting in reduced germination of Penicillium italicum in rind tissue. Among the induced flavonoids, quercetin glycosides, hesperetin, naringenin, diosmin and rutin were found (Yun et al., 2013) which further supports their role in disease resistance. As mentioned above, flavonoids are broad spectrum antimicrobial metabolites being active not only against fungal pathogens but also bacteria. The disease known as Huanglongbing (HLB) (or citrus greening) is caused by different strains of the Candidatus Liberibacter (Hijaz et al., 2013). A preliminary study carried out on symptomatic and control leaves of sweet orange plants indicated important changes in secondary metabolites (Manthey, 2008). Subsequent metabolomics studies revealed a primary accumulation of several hydroxycinnamates and certain selected flavonoids such as hesperidin, naringenin and quercetin (Cevallos-Cevallos et al., 2009; Hijaz et al., 2013). Although the specific role of these metabolites on bacterial growth and expansion has not been assessed, hesperidin accumulation in sweet orange has also been associated to defense mechanism against the bacterial pathogen Xylella fastidiosa (Soares et al., 2015).

Terpenoid phytoalexins often coexist with other of different origin; such is the case of the phenylpropanoid sakuranetin that is accumulated upon pathogen attack along with momilactones, oryzalexins and phytocassanes in rice and zealexin and kauralexin in corn, all of them diterpenes derived from geranyl geranyl pyrophosphate (Horie et al., 2015; Piasecka et al., 2015). About 20 genes involved in the biosynthesis of these compounds have been identified and investigated in rice, including several diterpene synthases (copalyl diphosphate synthases or CPS, kaurene synthases-like or KSL and P450 monooxygenases). Among all, CPS4 is involved in the biosynthesis of 
momilactones and oryzalexin S, as extracted from studies with a rice T-DNA insertion mutant cps4-tos devoid in both groups of terpenoid phytoalexins and also displayed significant sensitivity to rice blast fungus Magnaporthe oryzae and Fusarium fujikuroi responsible of the 'bakanae' or 'foolish seedling' disease (Piasecka et al., 2015). Nevertheless, although these plants showed significantly reduced levels of momilactones and oryzalexin S, they are not defective in the production of other terpenoid phytoalexins such as phytocassanes A to E and oryzalexins A to F; therefore, the putative role of these metabolites in rice immunity needs a further validation. The synthesis of zealexins and kauralexins is less understood, although it is thought that mediate interactions with microbial pathogens and insects in aerial tissues. However, recent studies have shown that anther ear 2 (an2) corn mutants deficient in kauralexin production are more prone to drought-induced damage (Vaughan et al., 2014). Under water deprivation, phytoalexin production is root-specific and does not have any effect in phytoalexin levels in shoots but could have an influence on the ability to induce their production in aboveground tissues. Moreover, treatment with the plant hormone ABA caused the accumulation of terpenoid phytoalexins in maize roots (Vaughan et al., 2015). Interestingly, in Nicotiana plumbaginifolia, the production of the sesquiterpenoid capsidiol was inhibited by ABA treatment (Mialoundama et al., 2009). Other phytoalexins are induced by jasmonates (Naoumkina et al., 2007) or SA (Durango et al. 2013). Citrus produce a large number of triterpenoids that have been associated to fruit and juice quality as well as responses of vegetative tissues to the environment. These compounds are synthesized from squalene by formation of a polycyclic molecule containing a furanolactone core structure; the main representative is limonin and its respective glucosylated form (Arbona et al., 2015). These compounds have been found to accumulate in vegetative Citrus tissues in response to HLB and could be part of the metabolic defense response (Manthey, 2008; Slisz et al., 2012).

ROS production and lipid peroxidation are major hallmarks of the HR in plants. The formation of lipid peroxides is catalyzed by lipoxygenases (LOX) and these molecules are involved in the execution of programmed cell death and also in signal transduction processes. In the cytoplasm, LOXs oxidize fatty acids rendering oxylipins that can diverge into the jasmonate or the hydroperoxide lyase biosynthesis pathways (Zoeller et al., 2012). Elicitation by pathogen attack or wounding induces cell membrane lipases that release linoleic acid from phospholipids into the cytoplasm (Aliferis and Jabaji, 
2012; Dat et al., 2005; Zoeller et al., 2012). Subsequently, LOX enzymes catalyze the formation lipid hydroperoxides. A central molecule is 13-hydroperoxy octadecatrienoic acid (13-HPOT) that can be further metabolized into 13-keto octadecatrienoic acid, cleaved into $n$-hexenal, or diverted into jasmonate biosynthetic pathway (Schaller, 2001). Besides jasmonates that do have a role in stress responses (De Ollas et al., 2015), fatty acid hydroperoxides have been shown to have a role in the induction of HR after pathogen attack (Dat et al., 2005; Zoeller et al., 2012) although cell death is not always associated with lipid peroxidation (Dat et al., 2005). In animal systems, lipid signaling plays an important role in the development of inflammatory response. As examples, the induction of leukotrienes and thromboxanes from arachidonic acid occurs in acute and chronic inflammatory processes (Hammond and O’Donnell, 2012). These responses are also downregulated after application of non-steroidal anti-inflammatory drugs such as acetyl salicylic acid or ibuprofen (Savchenko et al., 2010). Unlike animal systems, higher plants do not accumulate arachidonic acid; however, certain moss species such as the model bryophyte Physcomitrella patens are reported to contain significant amounts of this fatty acid; in addition, they also contain linoleic and linolenic acids (Beike et al., 2014) and accumulate cyclopentenone oxylipins (such as 12-oxo-phytodienoic acid, OPDA) but not jasmonic acid (Beike et al., 2014; Stumpe et al., 2010). Nevertheless, this fact does not seem to affect their ability to cope with biotic threats (Ponce de León et al., 2007), what means that other oxylipins might have taken over the role that JA and JA-Ile have in higher plants, reinforcing the hypothesis of lipid signaling as a transkingdom key feature in the response to infections.

In plant-pathogen interactions, much attention is paid to soluble semipolar metabolites as most phytoalexins and phytoanticipins fall within this category. However, successful pathogens subvert plant metabolism in order to enable the efficient uptake, sequestration and utilization of nutrients derived from the host photosynthetic activity. Under these circumstances, a reduction in net CO2 assimilation as well as a reprogramming of host carbon partitioning is often observed within the first stages of infection (Parker et al., 2009). It is expected that levels of polar metabolites from the primary metabolism: carbohydrates, aminoacids, tricarboxylic acids, etc. are affected by pathogen attack. In Arabidopsis thaliana, inoculation with Pseudomonas syringae caused metabolic changes that affected glucosinolates, phenolic compounds but also aminoacids (phenylalanine and tyrosine) and disaccharides (sucrose) (Ward et al., 
2010). Similarly, in symptomatic leaves of HLB affected citrus plants, phenylalanine accumulated whereas sucrose levels decreased (Chin et al., 2014), which indicates a different mode of action to that of $P$. syringae. Indeed, citrus varieties with enhanced susceptibility to HLB showed higher basal levels of L-proline, L-serine, and L-aspartic acid, galactose as well as butanedioic and tetradecanoic acids whereas resistant varieties showed higher levels of L-glycine and mannose. In addition, a stronger metabolic response was observed in sensitive varieties respect to resistant ones (Cevallos-Cevallos et al., 2012). Changes in primary metabolism indeed might influence the occurrence of secondary metabolites as their direct precursors. Therefore, microbes reprogram plants primary metabolism in order to provide themselves with nutrients; additionally, adapted plants might use this reprogramming to feed the secondary metabolism with precursors to synthesize lethal phytoalexins (Sanchez-Vallet et al., 2010). Moreover, it is also likely that plants respond to pathogen infection by reprogramming their own primary metabolism to deplete infected cells of the nutrients necessary to support microbial growth.

In response to pathogen elicitation, plants emit a number of volatile organic compounds (VOCs) that have several roles such as semiochemicals in plant-plant, plant-insect or plant-microbe interactions, responses to herbivore, biological control of entomological pests or invasive plants and as sensory and flavor attributes (Beck et al., 2014). Herbivory and fungal infections in different plant species induce the emission of several terpenes and fatty acid-derived volatiles that could be involved, directly or indirectly, in plant defense. For instance, when corn plants are attacked by herbivores synthesize $\beta$ caryophyllene from farnesyl diphosphate that is released to the atmosphere and attracts natural enemies of the herbivores (Beck et al., 2014). The induced VOC blend seems to exhibit attacker specificity and different strains of the same pathogen could induce different combinations of volatiles. Although their specific role is not yet clear, certain pathogen inducible volatile compounds such as 3-hexenol, 2-hexenal, methyl salicylate or linalool have been shown to inhibit pathogen growth (Ponzio et al., 2013). In corn, infection with different species of the phytophathogen Fusarium induced the production of diterpene VOCs ( $\beta$ - and $\alpha$-selinenes, $\beta$-macrocarpene, $\beta$-bisabolene and trichodiene) and their production correlated with the induction of zealexins (Becker et al., 2014). The specific role of these volatiles in infection response is not known although C6 green leaf volatiles have been associated to priming neighboring plants against pest attack (Beck et 
al., 2014). To this respect, it has been recently reported that the green leaf volatile 3hexenyl acetate enhances defense against Fusarium graminearum in wheat (Ameye et al., 2015). In citrus, downregulation of D-limonene synthase altered monoterpene levels and also induced resistance to Penicillium digitatum infection (Rodriguez et al., 2013). Conversely, overproduction of plant volatiles by transgenic Arabidopsis plants overexpressing a terpene synthase involved in monoterpene production (35S:TPS23/27) did not have a resistant behaviour against Verticillium longisporum. Released monoterpenes had a positive effect on conidial germination and hyphal growth subsequently allowing a faster colonization (Roos et al., 2015). As mentioned above, the role of VOCs as semiochemicals transferring information between individuals of the same plant species, different plant species and also different kingdoms is of ecological relevance (Morrell and Kessler, 2014). For instance, Candidatus Liberibacter Solanacearum alters the volatile emission spectra in the host tomato plant. A number of VOCs were more abundant in the headspace of infected plants than in control plants: $\alpha$ farnesene, $\alpha$-pinene, terpinen-4-ol, $\beta$-terpineol, $\alpha$-terpineol, and $\gamma$-terpineol along with aldehydes nonanal and octanal. This altered volatile emission influenced settlement behaviour of the Candidatus Liberibacter Solanacearum vector psyllid, as non-infected psyllids preferentially settle on an infected plant and non-infected plants attract infected psyllids (Mas et al., 2014). Other tri-trophic interactions have been described involving VOCs as mediators of this interaction, corn inoculation with the endophytic bacterium Enterobacter aerogenes increased resistance to blight fungus Setosphaeria turcica due to the increased production of 2,3-butanediol. However, these plants were more susceptible to the caterpillar Spodoptera litoralis (D’Alessandro et al., 2014), reinforcing the specificity of the VOCs blend production. Further research will focus in deciphering the specific roles of different VOCs blends and their implications in ecological interactions.

\section{Metabolic response of plants to viruses}

Viruses are invasive nucleic acids that use the host cell enzyme machinery to propagate throughout the entire organism. Infection of plants by viruses has different effects depending on virus-plant host compatibility, overall health status of plants, etc. Some viruses improve host plant quality and attractiveness to vectors (e.g. aphids), but other (e.g. Cucumber Mosaic Virus or CMV) significantly reduce plant 'appealing' through dramatic changes in phloem carbohydrate and aminoacid redistribution, resulting in 
massive dispersal of vectors. Interestingly, in CMV-infected squash there is an increase in volatile emission (but not in the particular VOCs blend) that exerts an attractive effect on vector aphids (Mauck et al., 2014). Therefore, it seems clear that also viruses subvert plant metabolism in order to facilitate their own dispersal. Another example found in the literature is the interaction of tobacco with Bemisia tabaci, the tobacco whitefly. Tobacco is a relatively poor host for B. tabaci but infection with tomato yellow leaf curl virus (TYLCV) increased host suitability associated to changes in volatile terpenoid synthesis (Luan et al., 2013). A similar response was observed in tomato, whiteflies preferred settling on TYLCV-infected plants that on healthy ones that have higher emissions of the volatile terpenes $\beta$-myrcene, thymene, $\beta$-phellandrene, caryophyllene, (+)-4-carene, and $\alpha$-humulene (Fang et al., 2013). In addition, there are also differences between resistant and susceptible cultivars. Tomato cultivars resistant to TYLCV exhibited a more coordinated response in the primary metabolism than susceptible ones, leading to the production of defensive secondary metabolites aimed to cope with the infection (Sade et al., 2014). There are also differences in locally-infected tissues or in organs that have developed a systemic response to the infection. For instance, in response to tomato mosaic virus (ToMV), tomato leaves responded to local infection by decreasing aminoacid, sucrose and phenolic acid levels and increasing tricarboxylic acid levels, systemic leaves showed similar profiles but also exhibited increased levels of tryptophan, sucrose and caffeoyl esters of glucaric acid. This was associated to a requirement of carbohydrates in locally-infected leaves to support the biosynthesis of defensive compounds such as rutin (López-Gresa et al., 2012). However, the specific role of changes in secondary metabolites on virus infection is not clear, as viruses are not real 'living' organisms and therefore their live cycle should not be affected by induced toxic compounds. A putative role of these metabolites could be directed to reduce virus spread by acting against the entomological vector. To ascertain the specific role, more in vitro and in vivo assays of potential defense compounds need to be performed both on virus replication and vector fitness.

\section{Conclusions and future prospects}

The now established high-throughput metabolite profiling techniques (LC/MS and GC/MS) have allowed the identification of a great number of novel molecules with putative antimicrobial, pathogen-growth deterring or semiotic functions. However, the great challenge is to undoubtedly assess their function in vivo. Modulation of toxic plant 
products to respond to pathogens could constitute a unique tool to enhance resistance, improving crop productivity and reducing pesticide application. Hence, metabolomics in combination with other -omics techniques have significantly contributed to the identification of genes and pathways responsible for the biosynthesis and accumulation of a plethora of secondary metabolites. As a result, a number of candidate genes for transgenic approaches are now available. However, it is important to properly assess any potential side effects of increasing phytoalexin production as these metabolites could be significantly toxic for human consumption. In addition, the host-pathogen interaction plasticity has also to be taken into account, as phytoalexin-overproducing transgenic crops could in turn drive adaptation of pathogens (Großkinsky et al., 2012). For these reasons, although substantial progress has been made towards the identification of genes and metabolites with potential antimicrobial activities and their implementation in crop improvement strategies (Table 1, see also Dubey et al., 2014), there is still a long way until researchers could fully understand the complex plantpathogen interactions.

\section{References}

Afek, U., and Sztejnberg, A. (1988). Accumulation of Scoparone, a Phytoalexin Associated with Resistance of Citrus to Phytophthora citrophthora. Phytophathology 78, 1678-1682.

Aharoni, A., Giri, A.P., Deuerlein, S., Griepink, F., de Kogel, W.-J., Verstappen, F.W.A., Verhoeven, H.A., Jongsma, M.A., Schwab, W., and Bouwmeester, H.J. (2003). Terpenoid metabolism in wild-type and transgenic Arabidopsis plants. Plant Cell 15, 2866-2884.

Ahmad, S., Veyrat, N., Gordon-Weeks, R., Zhang, Y., Martin, J., Smart, L., Glauser, G., Erb, M., Flors, V., Frey, M., et al. (2011). Benzoxazinoid metabolites regulate innate immunity against aphids and fungi in maize. Plant Physiol 157, 317-327.

Ahuja, I., Kissen, R., and Bones, A.M. (2012). Phytoalexins in defense against pathogens. Trends Plant Sci 17, 73-90.

Akamatsu, A., Wong, H.L., Fujiwara, M., Okuda, J., Nishide, K., Uno, K., Imai, K., Umemura, K., Kawasaki, T., Kawano, Y., et al. (2013). An OsCEBiP/OsCERK1OsRacGEF1-OsRac1 module is an essential early component of chitin-induced rice immunity. Cell Host Microbe 13, 465-476.

Aliferis, K. a., and Jabaji, S. (2012). FT-ICR/MS and GC-EI/MS metabolomics networking unravels global potato sprout's responses to Rhizoctonia solani infection. PLoS One 7, 1-13. 
Allwood, J.W., Ellis, D.I., and Goodacre, R. (2008). Metabolomic technologies and their application to the study of plants and plant-host interactions. Physiol Plant 132, 117-135.

Ameye, M., Audenaert, K., De Zutter, N., Steppe, K., Van Meulebroek, L., Vanhaecke, L., De Vleesschauwer, D., Haesaert, G., and Smagghe, G. (2015). Priming of Wheat with the Green Leaf Volatile Z-3-Hexenyl Acetate Enhances Defense against Fusarium graminearum But Boosts Deoxynivalenol Production. Plant Physiol 167, 1671-1684.

Arbona, V., Iglesias, D.J., Talón, M., and Gómez-Cadenas, A. (2009). Plant phenotype demarcation using nontargeted LC-MS and GC-MS metabolite profiling. J Agric Food Chem 57, 7338-7347.

Arbona, V., Iglesias, D.J., and Gómez-Cadenas, A. (2015). Non-targeted metabolite profiling of citrus juices as a tool for variety discrimination and metabolite flow analysis. BMC Plant Biol 15, 1-16.

Bahar, O., Pruitt, R., Luu, D.D., Schwessinger, B., Daudi, A., Liu, F., Ruan, R., Fontaine-Bodin, L., Koebnik, R., and Ronald, P. (2014). The Xanthomonas Ax21 protein is processed by the general secretory system and is secreted in association with outer membrane vesicles. PeerJ 2, e242.

Bar, M., Sharfman, M., Ron, M., and Avni, A. (2010). BAK1 is required for the attenuation of ethylene-inducing xylanase (Eix)-induced defense responses by the decoy receptor LeEix1. Plant J 63, 791-800.

Beck, J.J., Smith, L., and Baig, N. (2014). An overview of plant volatile metabolomics, sample treatment and reporting considerations with emphasis on mechanical damage and biological control of weeds. Phytochem Anal 25, 331-341.

Becker, E.-M., Herrfurth, C., Irmisch, S., Köllner, T.G., Feussner, I., Karlovsky, P., and Splivallo, R. (2014). Infection of corn ears by Fusarium spp. induces the emission of volatile sesquiterpenes. J Agric Food Chem 62, 5226-5236.

Bednarek, P., Pislewska-Bednarek, M., Svatos, A., Schneider, B., Doubsky, J., Mansurova, M., Humphry, M., Consonni, C., Panstruga, R., Sanchez-Vallet, A., et al. (2009). A glucosinolate metabolism pathway in living plant cells mediates broadspectrum antifungal defense. Science 323, 101-106.

Beike, A.K., Jaeger, C., Zink, F., Decker, E.L., and Reski, R. (2014). High contents of very long-chain polyunsaturated fatty acids in different moss species. Plant Cell Rep 33, 245-254.

Böttcher, C., von Roepenack-Lahaye, E., Schmidt, J., Schmotz, C., Neumann, S., Scheel, D., and Clemens, S. (2008). Metabolome analysis of biosynthetic mutants reveals a diversity of metabolic changes and allows identification of a large number of new compounds in Arabidopsis. Plant Physiol 147, 2107-2120.

Böttcher, C., von Roepenack-Lahaye, E., Schmidt, J., Clemens, S., and Scheel, D. (2009a). Analysis of phenolic choline esters from seeds of Arabidopsis thaliana and 
Brassica napus by capillary liquid chromatography/electrospray- tandem mass spectrometry. J Mass Spectrom 44, 466-476.

Böttcher, C., Westphal, L., Schmotz, C., Prade, E., Scheel, D., and Glawischnig, E. (2009b). The multifunctional enzyme CYP71B15 (PHYTOALEXIN DEFICIENT3) converts cysteine-indole-3-acetonitrile to camalexin in the indole-3-acetonitrile metabolic network of Arabidopsis thaliana. Plant Cell 21, 1830-1845.

Brillada, C., Nishihara, M., Shimoda, T., Garms, S., Boland, W., Maffei, M.E., and Arimura, G. (2013). Metabolic engineering of the C16 homoterpene TMTT in Lotus japonicus through overexpression of (E,E)-geranyllinalool synthase attracts generalist and specialist predators in different manners. New Phytol 200, 1200-1211.

Canel, C., Lopes-Cardoso, M.I., Whitmer, S., van der Fits, L., Pasquali, G., van der Heijden, R., Hoge, J.H.C., and Verpoorte, R. (1998). Effects of over-expression of strictosidine synthase and tryptophan decarboxylase on alkaloid production by cell cultures of Catharanthus roseus. Planta 205, 414-419.

Cevallos-Cevallos, J.M., Rouseff, R., and Reyes-De-Corcuera, J.I. (2009). Untargeted metabolite analysis of healthy and Huanglongbing-infected orange leaves by CE-DAD. Electrophoresis 30, 1240-1247.

Cevallos-Cevallos, J.M., Futch, D.B., Shilts, T., Folimonova, S.Y., and Reyes-DeCorcuera, J.I. (2012). GC-MS metabolomic differentiation of selected citrus varieties with different sensitivity to citrus huanglongbing. Plant Physiol Biochem 53, 69-76.

Chin, E.L., Mishchuk, D.O., Breksa, A.P., and Slupsky, C.M. (2014). Metabolite signature of candidatus liberibacter asiaticus infection in two citrus varieties. J Agric Food Chem 62, 6585-6591.

Chong, J. (2002). Downregulation of a Pathogen-Responsive Tobacco UDPGlc:Phenylpropanoid Glucosyltransferase Reduces Scopoletin Glucoside Accumulation, Enhances Oxidative Stress, and Weakens Virus Resistance. PLANT CELL ONLINE 14, 1093-1107.

Coll, N.S., Epple, P., and Dangl, J.L. (2011). Programmed cell death in the plant immune system. Cell Death Differ 18, 1247-1256.

Colliver, S.P., Morris, P., and Robbins, M.P. (1997). Differential modification of flavonoid and isoflavonoid biosynthesis with an antisense chalcone synthase construct in transgenic Lotus corniculatus. Plant Mol Biol 35, 509-522.

Cuadros-Inostroza, A., Caldana, C., Redestig, H., Kusano, M., Lisec, J., Peña-Cortés, H., Willmitzer, L., and Hannah, M. a (2009). TargetSearch--a Bioconductor package for the efficient preprocessing of GC-MS metabolite profiling data. BMC Bioinformatics $10,428$.

D’Alessandro, M., Erb, M., Ton, J., Brandenburg, A., Karlen, D., Zopfi, J., and Turlings, T.C.J. (2014). Volatiles produced by soil-borne endophytic bacteria increase 
plant pathogen resistance and affect tritrophic interactions. Plant Cell Environ 37, 813826.

Dardick, C., Schwessinger, B., and Ronald, P. (2012). Non-arginine-aspartate (non-RD) kinases are associated with innate immune receptors that recognize conserved microbial signatures. Curr Opin Plant Biol 15, 358-366.

Dat, J., Cotte, B. Van De, Montillet, J., Chamnongpol, S., Ruste, C., Breusegem, F. Van, Triantaphylide, C., Agnel, J., Battesti, C., and Inze, D. (2005). Fatty Acid Hydroperoxides and $\mathrm{H} 2 \mathrm{O} 2$ in the Execution of Hypersensitive Cell Death in Tobacco Leaves. Plant Physiol. 138, 1516-1526.

Deavours, B.E., and Dixon, R.A. (2005). Metabolic engineering of isoflavonoid biosynthesis in alfalfa. Plant Physiol 138, 2245-2259.

Delaunois, B., Cordelier, S., Conreux, A., Clément, C., and Jeandet, P. (2009). Molecular engineering of resveratrol in plants. Plant Biotechnol J 7, 2-12.

Dixon, R.A. (2001). Natural products and plant disease resistance. Nature 411, 843847.

Dixon, R.A., Achnine, L., Kota, P., Liu, C.-J., Reddy, M.S.S., and Wang, L. (2002). The phenylpropanoid pathway and plant defence-a genomics perspective. Mol Plant Pathol 3, 371-390.

Doares, S.H., Narvâez-Vâsquez, J., Conconi, A., and Ryan, C.A. (1995). Salicylic acid inhibits synthesis of proteinase inhibitors in tomato leaves induced by systemin and jasmonic acid. Plant Physiol 108, 1741-1746.

Du, H., Huang, Y., and Tang, Y. (2010). Genetic and metabolic engineering of isoflavonoid biosynthesis. Appl Microbiol Biotechnol 86, 1293-1312.

Dubey, S., Manduri, A., Arora, N., and Deepa Sankar, P. (2014). Transgenics in phytochemical defence. Res J Pharm Biol Chem Sci 5, 763-774.

Ebel, J., Ayers, A.R., and Albersheim, P. (1976). No Title. Plant Physiol. 57, 775-779.

Fang, Y., Jiao, X., Xie, W., Wang, S., Wu, Q., Shi, X., Chen, G., Su, Q., Yang, X., Pan, H., et al. (2013). Tomato yellow leaf curl virus alters the host preferences of its vector Bemisia tabaci. Sci Rep 3, 2876.

Friedman, M. (2002). Tomato glycoalkaloids: role in the plant and in the diet. J Agric Food Chem 50, 5751-5780.

Glawischnig, E. (2007). Camalexin. Phytochemistry 68, 401-406.

Glazebrook, J., and Ausubel, F.M. (1994). Isolation of phytoalexin-deficient mutants of Arabidopsis thaliana and characterization of their interactions with bacterial pathogens. Proc Natl Acad Sci U S A 91, 8955-8959. 
Gomez-Gomez, L. (2001). Both the Extracellular Leucine-Rich Repeat Domain and the Kinase Activity of FLS2 Are Required for Flagellin Binding and Signaling in Arabidopsis. PLANT CELL ONLINE 13, 1155-1163.

Gottstein, D., and Gross, D. (1992). Phytoalexins of woody plants. Trees 6, 55-68.

Großkinsky, D.K., Naseem, M., Abdelmohsen, U.R., Plickert, N., Engelke, T., Griebel, T., Zeier, J., Novák, O., Strnad, M., Pfeifhofer, H., et al. (2011). Cytokinins mediate resistance against Pseudomonas syringae in tobacco through increased antimicrobial phytoalexin synthesis independent of salicylic acid signaling. Plant Physiol 157, 815830.

Großkinsky, D.K., van der Graaff, E., and Roitsch, T. (2012). Phytoalexin transgenics in crop protection-Fairy tale with a happy end? Plant Sci 195, 54-70.

Grubb, C.D., and Abel, S. (2006). Glucosinolate metabolism and its control. Trends Plant Sci 11, 89-100.

Hammerschmidt, R. (1999). PHYTOALEXINS: What Have We Learned After 60 Years? Annu Rev Phytopathol 37, 285-306.

Hammond, V.J., and O’Donnell, V.B. (2012). Esterified eicosanoids: generation, characterization and function. Biochim Biophys Acta 1818, 2403-2412.

Harborne, J.B. (1999). The comparative biochemistry of phytoalexin induction in plants. Biochem Syst Ecol 27, 335-367.

Hasegawa, M., Mitsuhara, I., Seo, S., Okada, K., Yamane, H., Iwai, T., and Ohashi, Y. (2014). Analysis on blast fungus-responsive characters of a flavonoid phytoalexin sakuranetin; accumulation in infected rice leaves, antifungal activity and detoxification by fungus. Molecules 19, 11404-11418.

He, X.-Z. (2000). Genetic Manipulation of Isoflavone 7-O-Methyltransferase Enhances Biosynthesis of 4'-O-Methylated Isoflavonoid Phytoalexins and Disease Resistance in Alfalfa. PLANT CELL ONLINE 12, 1689-1702.

Hijaz, F.M., Manthey, J. a., Folimonova, S.Y., Davis, C.L., Jones, S.E., and Reyes-DeCorcuera, J.I. (2013). An HPLC-MS characterization of the changes in sweet orange leaf metabolite profile following infection by the bacterial pathogen Candidatus liberibacter asiaticus. PLoS One 8,1-15.

Horie, K., Inoue, Y., Sakai, M., Yao, Q., Tanimoto, Y., Koga, J., Toshima, H., and Hasegawa, M. (2015). Identification of UV-Induced Diterpenes Including a New Diterpene Phytoalexin, Phytocassane F, from Rice Leaves by Complementary GC/MS and LC/MS Approaches. J Agric Food Chem 63, 4050-4059.

Huffaker, A., Kaplan, F., Vaughan, M.M., Dafoe, N.J., Ni, X., Rocca, J.R., Alborn, H.T., Teal, P.E.A., and Schmelz, E.A. (2011). Novel acidic sesquiterpenoids constitute a dominant class of pathogen-induced phytoalexins in maize. Plant Physiol 156, 20822097. 
Huhman, D. V, Berhow, M. a, and Sumner, L.W. (2005). Quantification of saponins in aerial and subterranean tissues of Medicago truncatula. J Agric Food Chem 53, 1914 1920.

Ito, S.I., Eto, T., Tanaka, S., Yamauchi, N., Takahara, H., and Ikeda, T. (2004). Tomatidine and lycotetraose, hydrolysis products of??-tomatine by Fusarium oxysporum tomatinase, suppress induced defense responses in tomato cells. FEBS Lett 571, 31-34.

Jeandet, P. (2015). Phytoalexins: Current Progress and Future Prospects. Molecules 20, 2770-2774.

Jeandet, P., Douillet-Breuil, A.-C., Bessis, R., Debord, S., Sbaghi, M., and Adrian, M. (2002). Phytoalexins from the Vitaceae: Biosynthesis, Phytoalexin Gene Expression in Transgenic Plants, Antifungal Activity, and Metabolism. J Agric Food Chem 50, 27312741.

Jones, J.D.G., and Dangl, J.L. (2006). The plant immune system. Nature 444, 323-329.

Kaimoyo, E., and VanEtten, H.D. (2008). Inactivation of pea genes by RNAi supports the involvement of two similar O-methyltransferases in the biosynthesis of $(+)$-pisatin and of chiral intermediates with a configuration opposite that found in (+)-pisatin. Phytochemistry 69, 76-87.

Katajamaa, M., Miettinen, J., and Oresic, M. (2006). MZmine: toolbox for processing and visualization of mass spectrometry based molecular profile data. Bioinformatics 22, 634-636.

Kim, J.-A., Cho, K., Singh, R., Jung, Y.-H., Jeong, S.-H., Kim, S.-H., Lee, J.-E., Cho, Y.-S., Agrawal, G.K., Rakwal, R., et al. (2009). Rice OsACDR1 (Oryza sativa accelerated cell death and resistance 1 ) is a potential positive regulator of fungal disease resistance. Mol Cells 28, 431-439.

Kim, J.H., Lee, B.W., Schroeder, F.C., and Jander, G. (2008). Identification of indole glucosinolate breakdown products with antifeedant effects on Myzus persicae (green peach aphid). Plant J 54, 1015-1026.

Kmen, B., Etalo, D.W., Joosten, M.H. a J., Bouwmeester, H.J., de Vos, R.C.H., Collemare, J., and De Wit, P.J.G.M. (2013). Detoxification of $\alpha$-tomatine by Cladosporium fulvum is required for full virulence on tomato. New Phytol 198, 12031214.

Kurusu, T., Hamada, J., Hamada, H., Hanamata, S., and Kuchitsu, K. (2010). Roles of calcineurin B-like protein-interacting protein kinases in innate immunity in rice. Plant Signal Behav 5, 1045-1047.

Lieberei, R., Biehl, B., Giesemann, A., and Junqueira, N.T.V. (1989). Cyanogenesis inhibits active defense reactions in plants. Plant Physiol. 90, 33-36. 
Lipka, V., Dittgen, J., Bednarek, P., Bhat, R., Wiermer, M., Stein, M., Landtag, J., Brandt, W., Rosahl, S., Scheel, D., et al. (2005). Pre- and postinvasion defenses both contribute to nonhost resistance in Arabidopsis. Science 310, 1180-1183.

Liu, S., Hu, Y., Wang, X., Zhong, J., and Lin, Z. (2006). High content of resveratrol in lettuce transformed with a stilbene synthase gene of Parthenocissus henryana. J Agric Food Chem 54, 8082-8085.

Lommen, A. (2009). MetAlign: interface-driven, versatile metabolomics tool for hyphenated full-scan mass spectrometry data preprocessing. Anal Chem 81, 3079-3086.

López-Gresa, M.P., Lisón, P., Kim, H.K., Choi, Y.H., Verpoorte, R., Rodrigo, I., Conejero, V., and Bellés, J.M. (2012). Metabolic fingerprinting of Tomato Mosaic Virus infected Solanum lycopersicum. J Plant Physiol 169, 1586-1596.

Lu, D., Lin, W., Gao, X., Wu, S., Cheng, C., Avila, J., Heese, A., Devarenne, T.P., He, P., and Shan, L. (2011). Direct ubiquitination of pattern recognition receptor FLS2 attenuates plant innate immunity. Science 332, 1439-1442.

Luan, J.B., Yao, D.M., Zhang, T., Walling, L.L., Yang, M., Wang, Y.J., and Liu, S.S. (2013). Suppression of terpenoid synthesis in plants by a virus promotes its mutualism with vectors. Ecol Lett 16, 390-398.

Lücker, J., Bouwmeester, H.J., Schwab, W., Blaas, J., Van Der Plas, L.H.W., and Verhoeven, H.A. (2001). Expression of Clarkia S-linalool synthase in transgenic petunia plants results in the accumulation of S-linalyl- $\beta$-d-glucopyranoside. Plant J 27, 315-324.

Luedemann, A., Strassburg, K., Erban, A., and Kopka, J. (2008). TagFinder for the quantitative analysis of gas chromatography - mass spectrometry ( GC-MS ) based metabolite profiling experi- ments. Bioinformatics 1-7.

Macho, A.P., and Zipfel, C. (2014). Plant PRRs and the activation of innate immune signaling. Mol Cell 54, 263-272.

Mahmoud, S.S., and Croteau, R.B. (2001). Metabolic engineering of essential oil yield and composition in mint by altering expression of deoxyxylulose phosphate reductoisomerase and menthofuran synthase. Proc Natl Acad Sci U S A 98, 8915-8920.

Malik, M.S., Riley, M.B., Norsworthy, J.K., and Bridges, W. (2010). Variation of glucosinolates in wild radish (raphanus raphanistrum) accessions. J Agric Food Chem 58, 11626-11632.

Manthey, J.A. (2008). Differences in Secondary Metabolites in Leaves from Orange ( Citrus sinensis L .) Trees Affected with Greening Disease ( Huanglongbing ) ( HLB ). Proc Florida State Hortic Soc 121, 285-288.

Mas, F., Vereijssen, J., and Suckling, D.M. (2014). Influence of the pathogen Candidatus Liberibacter solanacearum on tomato host plant volatiles and psyllid vector settlement. J Chem Ecol 40, 1197-1202. 
Mauck, K.E., De Moraes, C.M., and Mescher, M.C. (2014). Biochemical and physiological mechanisms underlying effects of Cucumber mosaic virus on host-plant traits that mediate transmission by aphid vectors. Plant Cell Environ 37, 1427-1439.

Mert-Türk, F., Bennett, M.H., Mansfield, J.W., and Holub, E.B. (2003). Camalexin accumulation in Arabidopsis thaliana following abiotic elicitation or inoculation with virulent or avirulent Hyaloperonospora parasitica. Physiol Mol Plant Pathol 62, 137145.

Mialoundama, A.S., Heintz, D., Debayle, D., Rahier, A., Camara, B., and Bouvier, F. (2009). Abscisic acid negatively regulates elicitor-induced synthesis of capsidiol in wild tobacco. Plant Physiol 150, 1556-1566.

Mori, M., Tomita, C., Sugimoto, K., Hasegawa, M., Hayashi, N., Dubouzet, J.G., Ochiai, H., Sekimoto, H., Hirochika, H., and Kikuchi, S. (2007). Isolation and molecular characterization of a Spotted leaf 18 mutant by modified activation-tagging in rice. Plant Mol Biol 63, 847-860.

Morrell, K., and Kessler, A. (2014). Volatile-mediated information transfer and defence priming in plants: The scent of danger. Biochem (Lond) 36, 26-31.

Mugford, S.T., Louveau, T., Melton, R., Qi, X., Bakht, S., Hill, L., Tsurushima, T., Honkanen, S., Rosser, S.J., Lomonossoff, G.P., et al. (2013). Modularity of plant metabolic gene clusters: a trio of linked genes that are collectively required for acylation of triterpenes in oat. Plant Cell 25, 1078-1092.

Naoumkina, M., Farag, M. a, Sumner, L.W., Tang, Y., Liu, C.-J., and Dixon, R. a (2007). Different mechanisms for phytoalexin induction by pathogen and wound signals in Medicago truncatula. Proc Natl Acad Sci U S A 104, 17909-17915.

Nielsen, K.A., Hrmova, M., Nielsen, J.N., Forslund, K., Ebert, S., Olsen, C.E., Fincher, G.B., and Møller, B.L. (2006). Reconstitution of cyanogenesis in barley (Hordeum vulgare L.) and its implications for resistance against the barley powdery mildew fungus. Planta 223, 1010-1023.

Ohara, K., Ujihara, T., Endo, T., Sato, F., and Yazaki, K. (2003). Limonene production in tobacco with Perilla limonene synthase cDNA. J Exp Bot 54, 2635-2642.

Okada, K. (2014). The Biosynthesis of Isoprenoids and the Mechanisms Regulating It in Plants. Biosci Biotechnol Biochem 75, 1219-1225.

De Ollas, C., Arbona, V., and Gómez-Cadenas, A. (2015). Jasmonoyl isoleucine accumulation is needed for abscisic acid build-up in roots of Arabidopsis under water stress conditions. Plant Cell Environ n/a - n/a.

Ono, E., Wong, H.L., Kawasaki, T., Hasegawa, M., Kodama, O., and Shimamoto, K. (2001). Essential role of the small GTPase Rac in disease resistance of rice. Proc Natl Acad Sci U S A 98, 759-764. 
Ortuño, a, Arcas, M.C., Botía, J.M., Fuster, M.D., and Del Río, J. a (2002). Increasing resistance against Phytophthora citrophthora in tangelo Nova fruits by modulating polymethoxyflavones levels. J Agric Food Chem 50, 2836-2839.

Park, C.-J., Peng, Y., Chen, X., Dardick, C., Ruan, D., Bart, R., Canlas, P.E., and Ronald, P.C. (2008). Rice XB15, a protein phosphatase 2C, negatively regulates cell death and XA21-mediated innate immunity. PLoS Biol 6, e231.

Parker, D., Beckmann, M., Zubair, H., Enot, D.P., Caracuel-Rios, Z., Overy, D.P., Snowdon, S., Talbot, N.J., and Draper, J. (2009). Metabolomic analysis reveals a common pattern of metabolic re-programming during invasion of three host plant species by Magnaporthe grisea. Plant J 59, 723-737.

Parkhi, V., Kumar, V., Campbell, L.M., Bell, A.A., Shah, J., and Rathore, K.S. (2010). Resistance against various fungal pathogens and reniform nematode in transgenic cotton plants expressing Arabidopsis NPR1. Transgenic Res 19, 959-975.

Pedras, M.S.C., and Adio, A.M. (2008). Phytoalexins and phytoanticipins from the wild crucifers Thellungiella halophila and Arabidopsis thaliana: rapalexin A, wasalexins and camalexin. Phytochemistry 69, 889-893.

Pedras, M.S.C., Adio, A.M., Suchy, M., Okinyo, D.P.O., Zheng, Q.-A., Jha, M., and Sarwar, M.G. (2006). Detection, characterization and identification of crucifer phytoalexins using high-performance liquid chromatography with diode array detection and electrospray ionization mass spectrometry. J Chromatogr A 1133, 172-183.

Pedras, M.S.C., Zheng, Q.A., and Strelkov, S. (2008). Metabolic changes in roots of the oilseed canola infected with the biotroph Plasmodiophora brassicae: Phytoalexins and phytoanticipins. J Agric Food Chem 56, 9949-9961.

Perrin, D.R., and Bottomley, W. (1961). Pisatin: an Antifungal Substance from Pisum sativum L. Nature 191, 76-77.

Piasecka, A., Jedrzejczak-rey, N., and Bednarek, P. (2015). Tansley review Secondary metabolites in plant innate immunity: conserved function of divergent chemicals. New Phytol 206, 948-964.

Pluskal, T., Castillo, S., Villar-Briones, A., and Oresic, M. (2010). MZmine 2: modular framework for processing, visualizing, and analyzing mass spectrometry-based molecular profile data. BMC Bioinformatics 11, 395.

Ponce de León, I., Oliver, J.P., Castro, A., Gaggero, C., Bentancor, M., and Vidal, S. (2007). Erwinia carotovora elicitors and Botrytis cinerea activate defense responses in Physcomitrella patens. BMC Plant Biol 7, 52.

Ponzio, C., Gols, R., Pieterse, C.M.J., and Dicke, M. (2013). Ecological and phytohormonal aspects of plant volatile emission in response to single and dual infestations with herbivores and phytopathogens. Funct Ecol 27, 587-598. 
Rasmann, S., Köllner, T.G., Degenhardt, J., Hiltpold, I., Toepfer, S., Kuhlmann, U., Gershenzon, J., and Turlings, T.C.J. (2005). Recruitment of entomopathogenic nematodes by insect-damaged maize roots. Nature 434, 732-737.

Rauhut, T., Luberacki, B., Seitz, H.U., and Glawischnig, E. (2009). Inducible expression of a Nep1-like protein serves as a model trigger system of camalexin biosynthesis. Phytochemistry 70, 185-189.

Ren, D., Liu, Y., Yang, K.-Y., Han, L., Mao, G., Glazebrook, J., and Zhang, S. (2008). A fungal-responsive MAPK cascade regulates phytoalexin biosynthesis in Arabidopsis. Proc Natl Acad Sci U S A 105, 5638-5643.

Del Río, J. a, Gómez, P., Baidez, a G., Arcas, M.C., Botía, J.M., and Ortuño, a (2004). Changes in the levels of polymethoxyflavones and flavanones as part of the defense mechanism of Citrus sinensis (cv. Valencia Late) fruits against Phytophthora citrophthora. J Agric Food Chem 52, 1913-1917.

Robert-Seilaniantz, A., MacLean, D., Jikumaru, Y., Hill, L., Yamaguchi, S., Kamiya, Y., and Jones, J.D.G. (2011). The microRNA miR393 re-directs secondary metabolite biosynthesis away from camalexin and towards glucosinolates. Plant J 67, 218-231.

Rodriguez, A., Shimada, T., Cervera, M., Alquezar, B., Gadea, J., Gomez-Cadenas, A., De Ollas, C.J., Rodrigo, M.J., Zacarias, L., and Pena, L. (2013). Terpene DownRegulation Triggers Defense Responses in Transgenic Orange Leading to Resistance against Fungal Pathogens. PLANT Physiol 164, 321-339.

Roessner, U., Luedemann, a, Brust, D., Fiehn, O., Linke, T., Willmitzer, L., and Fernie, a (2001). Metabolic profiling allows comprehensive phenotyping of genetically or environmentally modified plant systems. Plant Cell 13, 11-29.

Roos, J., Bejai, S., Mozūraitis, R., and Dixelius, C. (2015). Susceptibility to Verticillium longisporum is linked to monoterpene production by TPS23/27 in Arabidopsis. Plant J 81, 572-585.

Sade, D., Shriki, O., Cuadros-Inostroza, A., Tohge, T., Semel, Y., Haviv, Y., Willmitzer, L., Fernie, A.R., Czosnek, H., and Brotman, Y. (2014). Comparative metabolomics and transcriptomics of plant response to Tomato yellow leaf curl virus infection in resistant and susceptible tomato cultivars. Metabolomics 11, 81-97.

Sanchez-Vallet, A., Ramos, B., Bednarek, P., López, G., Piślewska-Bednarek, M., Schulze-Lefert, P., and Molina, A. (2010). Tryptophan-derived secondary metabolites in Arabidopsis thaliana confer non-host resistance to necrotrophic Plectosphaerella cucumerina fungi. Plant J 63, 115-127.

Sandrock, R.W., and VanEtten, H.D. (2001). The relevance of tomatinase activity in pathogens of tomato: disruption of the $\beta 2$-tomatinase gene inColletotrichum coccodes and Septoria lycopersici and heterologous expression of the Septoria lycopersici $\beta 2$ tomatinase in Nectria haematococca, a pathogen o. Physiol Mol Plant Pathol 58, 159171. 
Savchenko, T., Walley, J.W., Chehab, E.W., Xiao, Y., Kaspi, R., Pye, M.F., Mohamed, M.E., Lazarus, C.M., Bostock, R.M., and Dehesh, K. (2010). Arachidonic acid: an evolutionarily conserved signaling molecule modulates plant stress signaling networks. Plant Cell 22, 3193-3205.

Sawada, K., Hasegawa, M., Tokuda, L., Kameyama, J., Kodama, O., Kohchi, T., Yoshida, K., and Shinmyo, A. (2004). Enhanced resistance to blast fungus and bacterial blight in transgenic rice constitutively expressing OsSBP, a rice homologue of mammalian selenium-binding proteins. Biosci Biotechnol Biochem 68, 873-880.

Schaller, F. (2001). Enzymes of the biosynthesis of octadecanoid-derived signalling molecules. J Exp Bot 52, 11-23.

Schlaeppi, K., Abou-Mansour, E., Buchala, A., and Mauch, F. (2010). Disease resistance of Arabidopsis to Phytophthora brassicae is established by the sequential action of indole glucosinolates and camalexin. Plant J 62, 840-851.

Shimizu, T., Nakano, T., Takamizawa, D., Desaki, Y., Ishii-Minami, N., Nishizawa, Y., Minami, E., Okada, K., Yamane, H., Kaku, H., et al. (2010). Two LysM receptor molecules, CEBiP and OsCERK1, cooperatively regulate chitin elicitor signaling in rice. Plant J 64, 204-214.

Slisz, A.M., Breksa, A.P., Mishchuk, D.O., McCollum, G., and Slupsky, C.M. (2012). Metabolomic analysis of citrus infection by "Candidatus Liberibacter" reveals insight into pathogenicity. J Proteome Res 11, 4223-4230.

Smith, C. a, Want, E.J., O’Maille, G., Abagyan, R., and Siuzdak, G. (2006). XCMS: processing mass spectrometry data for metabolite profiling using nonlinear peak alignment, matching, and identification. Anal. Chem. 78, 779-787.

Snyder, B.A., and Nicholson, R.L. (1990). Synthesis of phytoalexins in sorghum as a site-specific response to fungal ingress. Science (80- ) 248, 1637-1639.

Soares, M.S., da Silva, D.F., Forim, M.R., da Silva, M.F.D.G.F., Fernandes, J.B., Vieira, P.C., Silva, D.B., Lopes, N.P., de Carvalho, S.A., de Souza, A.A., et al. (2015). Quantification and localization of hesperidin and rutin in Citrus sinensis grafted on C. limonia after Xylella fastidiosa infection by HPLC-UV and MALDI imaging mass spectrometry. Phytochemistry.

Strehmel, N., Kopka, J., Scheel, D., and Böttcher, C. (2013). Annotating unknown components from GC/EI-MS-based metabolite profiling experiments using GC/APCI(+)-QTOFMS. Metabolomics 1-13.

Stukkens, Y., Bultreys, A., Grec, S., Trombik, T., Vanham, D., and Boutry, M. (2005). NpPDR1, a pleiotropic drug resistance-type ATP-binding cassette transporter from Nicotiana plumbaginifolia, plays a major role in plant pathogen defense. Plant Physiol 139, 341-352.

Stumpe, M., Göbel, C., Faltin, B., Beike, A.K., Hause, B., Himmelsbach, K., Bode, J., Kramell, R., Wasternack, C., Frank, W., et al. (2010). The moss Physcomitrella patens 
contains cyclopentenones but no jasmonates: mutations in allene oxide cyclase lead to reduced fertility and altered sporophyte morphology. New Phytol 188, 740-749.

Sun, Y., Han, Z., Tang, J., Hu, Z., Chai, C., Zhou, B., and Chai, J. (2013). Structure reveals that BAK1 as a co-receptor recognizes the BRI1-bound brassinolide. Cell Res 23, 1326-1329.

Tijerino, A., Hermosa, R., Cardoza, R.E., Moraga, J., Malmierca, M.G., Aleu, J., Collado, I.G., Monte, E., and Gutierrez, S. (2011). Overexpression of the Trichoderma brevicompactum tri5 gene: effect on the expression of the trichodermin biosynthetic genes and on tomato seedlings. Toxins (Basel) 3, 1220-1232.

Tikunov, Y., Lommen, A., Vos, C.H.R. De, Verhoeven, H.A., Bino, R.J., Hall, R.D., and Bovy, A.G. (2005). A Novel Approach for Nontargeted Data Analysis for Metabolomics . Large-Scale Profiling of Tomato Fruit Volatiles 1 [ w ]. 139, 11251137.

Treutter, D. (2006). Significance of flavonoids in plant resistance: a review. Environ. Chem. Lett. 4, 147-157.

Treviño, V., Yañez-Garza, I.-L., Rodriguez-López, C.E., Urrea-López, R., GarzaRodriguez, M.-L., Barrera-Saldaña, H.-A., Tamez-Peña, J.G., Winkler, R., and Díaz dela-Garza, R.-I. (2015). GridMass: a fast two-dimensional feature detection method for LC/MS. J Mass Spectrom 50, 165-174.

Vaughan, M.M., Christensen, S., Schmelz, E.A., Huffaker, A., McAuslane, H.J., Alborn, H.T., Romero, M., Allen, L.H., and Teal, P.E.A. (2014). Accumulation of terpenoid phytoalexins in maize roots is associated with drought tolerance. Plant Cell Environ.

Vaughan, M.M., Christensen, S., Schmelz, E. a., Huffaker, A., Mcauslane, H.J., Alborn, H.T., Romero, M., Allen, L.H., and Teal, P.E. a. (2015). Accumulation of terpenoid phytoalexins in maize roots is associated with drought tolerance. Plant Cell Environ n/a $-\mathrm{n} / \mathrm{a}$.

Velasco, P., Francisco, M., Moreno, D. a., Ferreres, F., García-Viguera, C., and Cartea, M.E. (2011). Phytochemical fingerprinting of vegetable Brassica oleracea and Brassica napus by simultaneous identification of glucosinolates and phenolics. Phytochem Anal 22, 144-152.

Vogt, T. (2010). Phenylpropanoid biosynthesis. Mol Plant 3, 2-20.

Wang, E., Wang, R., DeParasis, J., Loughrin, J.H., Gan, S., and Wagner, G.J. (2001). Suppression of a P450 hydroxylase gene in plant trichome glands enhances naturalproduct-based aphid resistance. Nat Biotechnol 19, 371-374.

Ward, J.L., Forcat, S., Beckmann, M., Bennett, M., Miller, S.J., Baker, J.M., Hawkins, N.D., Vermeer, C.P., Lu, C., Lin, W., et al. (2010). The metabolic transition during disease following infection of Arabidopsis thaliana by Pseudomonas syringae pv. tomato. Plant J 1-15. 
Williams, C. a, and Grayer, R.J. (2004). Anthocyanins and other flavonoids. Nat Prod Rep 21, 539-573.

Wu, Q., and VanEtten, H.D. (2004). Introduction of plant and fungal genes into pea (Pisum sativum L.) hairy roots reduces their ability to produce pisatin and affects their response to a fungal pathogen. Mol Plant-Microbe Interact 17, 798-804.

Wu, S., Schalk, M., Clark, A., Miles, R.B., Coates, R., and Chappell, J. (2006). Redirection of cytosolic or plastidic isoprenoid precursors elevates terpene production in plants. Nat Biotechnol 24, 1441-1447.

Yun, Z., Gao, H., Liu, P., Liu, S., Luo, T., Jin, S., Xu, Q., Xu, J., Cheng, Y., and Deng, X. (2013). Comparative proteomic and metabolomic profiling of citrus fruit with enhancement of disease resistance by postharvest heat treatment. BMC Plant Biol 13, 44.

Zandalinas, S.I., Vives-Peris, V., Gómez-Cadenas, A., and Arbona, V. (2012). A fast and precise method to identify indolic glucosinolates and camalexin in plants by combining mass spectrometric and biological information. J Agric Food Chem 60, 8648-8658.

Zhurov, V., Navarro, M., Bruinsma, K. a, Arbona, V., Santamaria, M.E., Cazaux, M., Wybouw, N., Osborne, E.J., Ens, C., Rioja, C., et al. (2014). Reciprocal Responses in the Interaction between Arabidopsis and the Cell-Content-Feeding Chelicerate Herbivore Spider Mite. Plant Physiol 164, 384-399.

Zoeller, M., Stingl, N., Krischke, M., Fekete, A., Waller, F., Berger, S., and Mueller, M.J. (2012). Lipid profiling of the Arabidopsis hypersensitive response reveals specific lipid peroxidation and fragmentation processes: biogenesis of pimelic and azelaic acid. Plant Physiol 160, 365-378. 
Table 1. Transgenic strategies to enhance secondary metabolite production and plant defense against pathogens (adapted from (Dubey et al., 2014; Großkinsky et al., 2012)).

\begin{tabular}{|c|c|c|c|c|}
\hline $\begin{array}{l}\text { Metabolite } \\
\text { class }\end{array}$ & Plant species & $\begin{array}{l}\text { Target } \\
\text { secondary } \\
\text { metabolite }\end{array}$ & Transgenic strategy/genetic modification & Observed result \\
\hline \multicolumn{5}{|l|}{ Alkaloids } \\
\hline & Arabidopsis thaliana & Camalexin & $\begin{array}{l}\text { Knock out of phytoalexin deficient } 3 \text { (PAD3), } \\
\text { responsible of the last step in camalexin } \\
\text { biosynthesis (Böttcher et al., 2009b) }\end{array}$ & $\begin{array}{l}\text { Decreased camalexin, biosynthesis, no effect on } \\
\text { Pseudomonas syringae infection (Glazebrook and Ausubel, } \\
\text { 1994). }\end{array}$ \\
\hline & & & EtOH-inducible oomycete elicitor (PaNie) & $\begin{array}{l}\text { Time-dependent induction of tryptophan and camalexin } \\
\text { biosynthesis genes by PaNie (Rauhut et al., 2009). }\end{array}$ \\
\hline & & & Overexpression of $m i R 393$ & $\begin{array}{l}\text { Re-direction of secondary metabolism from camalexin to } \\
\text { glucosinolates, increased resistance against Pseudomonas } \\
\text { syringae and Hyaloperonospora parasitica, increased } \\
\text { susceptibility against Alternaria brassicicola (Robert- } \\
\text { Seilaniantz et al., 2011). }\end{array}$ \\
\hline & & & $\begin{array}{l}\text { Dexamethasone inducible overexpression of } \\
M E K 2 ; m p k 3 / m p k 6 \text { knock out }\end{array}$ & $\begin{array}{l}\text { Camalexin accumulation after MEK2 induction, } \\
\text { reduced/delayed camalexin biosynthesis in mpk3 and mpk6 } \\
\text { mutant lines, increased susceptibility against Botrytis } \\
\text { cinerea of } m p k 3 \text { mutant line (Ren et al., 2008). }\end{array}$ \\
\hline & & & Knock out of WRKY33 & $\begin{array}{l}\text { Reduced camalexin levels in wrky33 mutant lines (Ahuja et } \\
\text { al., 2012). }\end{array}$ \\
\hline & Catharanthus roseus & Strictosidine & $\begin{array}{l}\text { Overexpression of tryptophan decarboxylase } \\
\text { and strictosidine synthase }\end{array}$ & Increased alkaloid production (Canel et al., 1998). \\
\hline \multicolumn{5}{|l|}{ Terpenoids } \\
\hline & Oryza sativa & Momilactones & $\begin{array}{l}\text { Overexpression of transcription factor (e.g. } \\
\text { OsTGAP1) and biosynthesis genes } \\
\text { Knock down of biosynthesis genes }\end{array}$ & $\begin{array}{l}\text { Increased momilactone levels in overexpression lines, } \\
\text { constitutive momilactone accumulation in OsTGAP1 } \\
\text { overexpression lines, reduced momilactone levels in knock } \\
\text { down lines (Okada, 2014) }\end{array}$ \\
\hline & & & $\begin{array}{l}\text { CIPK14/15 RNAi and overexpression of } \\
\text { CIPK15 }\end{array}$ & $\begin{array}{l}\text { Decreased momilatone accumulation in CIPK14/15 RNAi- } \\
\text { line, increased momilactone accumulation in CIPK15 } \\
\text { overexpression line (Kurusu et al., 2010) }\end{array}$ \\
\hline & & Momilactone A & Overexpression of Accelerated Cell Death and & Increased momilactone A accumulation and increased \\
\hline
\end{tabular}




\begin{tabular}{|c|c|c|c|}
\hline & & $\begin{array}{l}\text { Resistance } 1 \text { (ACDR1) a putative Raf-like } \\
\text { MAPKKK. }\end{array}$ & $\begin{array}{l}\text { resistance against Magnaporthe grisea in ACDR1 } \\
\text { overexpression lines (Kim et al., 2009). }\end{array}$ \\
\hline & & Spotted leaf 18 Spl18 mutant & $\begin{array}{l}\text { Increased momilactone A accumulation and increased } \\
\text { resistance against Magnaporthe grisea in spl18 mutant } \\
\text { (Mori et al., 2007). }\end{array}$ \\
\hline & & Overexpression of Rac GTPAse (RAC1) & $\begin{array}{l}\text { Increased momilactone A accumulation and increased } \\
\text { resistance against Xanthomonas oryzae in RAC1 } \\
\text { overexpression lines (Ono et al., 2001). }\end{array}$ \\
\hline & & $\begin{array}{l}\text { Overexpression of } S B P \text {, a Se binding protein } \\
\text { involved in plant defense. }\end{array}$ & $\begin{array}{l}\text { Increased momilactone A accumulation an increased } \\
\text { resistance against Magnaporthe grisea and Xanthomonas } \\
\text { oryzae in SBP overexpression lines (Sawada et al., 2004). }\end{array}$ \\
\hline & $\beta$-caryophyllene & $\begin{array}{l}\text { Overexpression of OsTPS3 encoding a beta- } \\
\text { caryophyllene synthase }\end{array}$ & $\begin{array}{l}\text { Plants with increased emission rates of (E)- } \beta \text {-caryophyllene } \\
\text { (Ohara et al., 2003). }\end{array}$ \\
\hline & Phytocassanes & $\begin{array}{l}\text { CIPK14/15 RNAi and overexpression of } \\
\text { CIPK15 }\end{array}$ & $\begin{array}{l}\text { Decreased phytocassane accumulation in CIPK14/15 } \\
\text { RNAi-line, increased phytocassane accumulation in } \\
\text { CIPK15 overexpression line (Kurusu et al., 2010). }\end{array}$ \\
\hline Nicotiana tabacum & Capsidiol & $\begin{array}{l}\text { Overexpression of isopentenyl transferase } \\
\text { (ipt) }\end{array}$ & $\begin{array}{l}\text { Induction of capsidiol biosynthesis and increased resistance } \\
\text { against Pseudomonas syringae, increased susceptibility to } \\
\text { Botrytis cinerea (Großkinsky et al., 2011). }\end{array}$ \\
\hline & Trichodiene & $\begin{array}{l}\text { Over expression of trichodiene synthase gene, } \\
\text { that converts farnesyl pyrophosphate to } \\
\text { trichodiene - Inserted under constitutive action } \\
\text { of CaMV35S }\end{array}$ & $\begin{array}{l}\text { Expression of active enzyme, increases the production of } \\
\text { the sesquiterpenoid product in leaves (Tijerino et al., 2011). }\end{array}$ \\
\hline & Monoterpenes & $\begin{array}{l}\text { Expression of Perilla frutescens limonene } \\
\text { synthase }\end{array}$ & Increased synthesis of limonene (Doares et al., 1995). \\
\hline & $\begin{array}{l}\text { Patchoulol and } \\
\text { sesquiterpenes }\end{array}$ & Overexpression of patchoulol synthase. & $\begin{array}{l}\text { Catalyses the conversion of 2E,6E-Farnesyl diphosphate to } \\
\text { patchoulol and diphosphate. Synthesis of patchoulol } \\
\text { (volatile) and } 13 \text { additional sesquiterpene products } \\
\text { (Rasmann et al., 2005). }\end{array}$ \\
\hline & Cembratrienol & $\begin{array}{l}\text { Antisense co-suppression of Cytochrome } \\
\text { P450 hydroxylase gene specific to the } \\
\text { trichome gland Involved in metabolism of } \\
\text { sesquiterpenoids }\end{array}$ & $\begin{array}{l}\text { Exudates of transgenic plants contain high concentrations } \\
\text { of cembratrieneol and showed lower aphid predation (Wang } \\
\text { et al., 2001). }\end{array}$ \\
\hline $\begin{array}{l}\text { Nicotiana } \\
\text { plumbaginifolia }\end{array}$ & & ABA deficient mutants Npaba1 and 2 & $\begin{array}{l}\text { Increased capsidiol accumulation in Npaba1 and Npaba2 } \\
\text { mutant lines (Mialoundama et al., 2009). }\end{array}$ \\
\hline Mentha $\times$ piperita $L$. & Several & Co-suppression of 1-deoxy-d-xylulose-5- & Transgenic plants showed a lower yield loss due to pests \\
\hline
\end{tabular}




\begin{tabular}{|c|c|c|c|c|}
\hline & & terpenoids & $\begin{array}{l}\text { phosphate reducto-isomerase (DXR). En } \\
\text { enzyme that catalyzes the first committed step } \\
\text { of methyl erythritiol phosphate (MEP) } \\
\text { pathway }\end{array}$ & and pathogens (Mahmoud and Croteau, 2001). \\
\hline & $\begin{array}{l}\text { Petunia hybrida, } \\
\text { Solanum } \\
\text { lycopersicum, } \\
\text { Dianthus } \\
\text { caryophyllus }\end{array}$ & Linalool & $\begin{array}{l}\text { Constitutive over expression in flowers of S- } \\
\text { linalool synthase that catalyzes the conversion } \\
\text { of geranyl diphosphate to 3S-linalool }\end{array}$ & $\begin{array}{l}\text { Linalool and its derivatives produced by the transgenic } \\
\text { plants act as repellents of Myzus persicae aphids and } \\
\text { associated pathogens (Lücker et al., 2001). }\end{array}$ \\
\hline & Nicotiana spp. & $\begin{array}{l}\text { Volatile } \\
\text { terpenoids, } \\
\text { sclareol }\end{array}$ & NpPDR1 overexpression, an ABC transporter. & $\begin{array}{l}\text { Increased volatile diterpene emission and sclareol secretion } \\
\text { upon elicitation with pathogens (Aharoni et al., 2003; } \\
\text { Stukkens et al., 2005). }\end{array}$ \\
\hline & Artimisia annua & sesquiterpenoids & $\begin{array}{l}\text { Overexpression of farnesyl diphosphate } \\
\text { synthase }\end{array}$ & $\begin{array}{l}\text { Increased metabolic flux in the sesquiterpenoid biosynthetic } \\
\text { pathway (Doares et al., 1995). }\end{array}$ \\
\hline & $\begin{array}{l}\text { Lotus japonicus } \\
\text { Nicotiana tabacum }\end{array}$ & $\begin{array}{l}\text { (E,E)-geranyl } \\
\text { linalool and } \\
4,8,12- \\
\text { trimethyltrideca } \\
-1,3,7,11- \\
\text { tetraene } \\
\text { (TMTT) }\end{array}$ & $\begin{array}{l}\text { Terpene synthase gene }- \text { PITPS2 from } \\
\text { Phaseolus lunatus }\end{array}$ & $\begin{array}{l}\text { Transgenic plants produce (E,E)-geranyl linalool and } \\
\text { 4,8,12-trimethyltrideca-1,3,7,11-tetraene (TMTT). Attracts } \\
\text { predatory mites to infested plants (Wu et al., 2006). }\end{array}$ \\
\hline & Gossypium hirsutum & Gossypol & $\begin{array}{l}\text { Overexpression of NPR1, that controls } \\
\text { systemic acquired resistance (SAR). }\end{array}$ & $\begin{array}{l}\text { Increased gossypol accumulation and increased resistance } \\
\text { against Rhizoctonia solani and Alternaria alternata in } \\
\text { NPR1 overexpression lines (Parkhi et al., 2010). }\end{array}$ \\
\hline \multicolumn{5}{|l|}{$\begin{array}{l}\text { Phenylpropano } \\
\text { id pathway }\end{array}$} \\
\hline \multirow[t]{3}{*}{$\begin{array}{l}\text { Cinnamates/Co } \\
\text { umarins }\end{array}$} & Nicotiana tabacum & Scopoletin & $\begin{array}{l}\text { Overexpression of isopentenyl transferase } \\
\text { (ipt) gene. }\end{array}$ & $\begin{array}{l}\text { Induction of capsidiol biosynthesis and increased resistance } \\
\text { against Pseudomonas syringae, increased susceptibility to } \\
\text { Botrytis cinerea (Großkinsky et al., 2011). }\end{array}$ \\
\hline & & & $\begin{array}{l}\text { Antisense expression of Tobacco O-glucosyl } \\
\text { Transferase (TOGT) gene. }\end{array}$ & $\begin{array}{l}\text { Reduced scopoletin accumulation and increased TMV } \\
\text { susceptibility in TOGT antisense lines (Chong, 2002). }\end{array}$ \\
\hline & $\begin{array}{l}\text { Solanum } \\
\text { lycopersicum }\end{array}$ & $\begin{array}{l}\text { Increased } \\
\text { oxidation } \\
\text { phenolic } \\
\text { substrates }\end{array}$ & $\begin{array}{l}\text { cDNA transfer of polyphenol oxidase gene } \\
\text { from Solanum tuberosum under constitutive } \\
\text { action of CMV35S }\end{array}$ & $\begin{array}{l}\text { Transgenic plants showed increased resistance to } \\
\text { Pseudomonas syringae and strong inhibition of bacterial } \\
\text { growth (Brillada et al., 2013). }\end{array}$ \\
\hline Flavones & Arabidopsis thaliana, & Medicarpin & Overexpression of chalcone isomerase $(\mathrm{CHI})$ & Increased flavonol levels in $C H I$ overexpression lines \\
\hline
\end{tabular}




\begin{tabular}{|c|c|c|c|c|}
\hline \multirow[t]{9}{*}{ Isoflavones } & \multirow{2}{*}{\multicolumn{2}{|c|}{$\begin{array}{l}\text { Solanum } \\
\text { lycopersicum, } \\
\text { Medicago sativa }\end{array}$}} & \multirow{2}{*}{$\begin{array}{l}\text { gene. } \\
\text { Overexpression of isoflavone } O \text {-methyl } \\
\text { transferase }(I O M T) \text {. }\end{array}$} & \multirow{2}{*}{$\begin{array}{l}\text { (Dixon et al., 2002). } \\
\text { Increased medicarpin accumulation and increased } \\
\text { resistance against Phoma medicaginis in IOMT } \\
\text { overexpression lines (Dixon et al., 2002) }\end{array}$} \\
\hline & & & & \\
\hline & Several plant species & $\begin{array}{l}\text { e.g. Coumestrol, } \\
\text { Glyceollins, } \\
\text { Medicarpin }\end{array}$ & $\begin{array}{l}\text { Various modulations of biosynthesis genes } \\
\text { and regulatory elements }\end{array}$ & Diverse (Du et al., 2010). \\
\hline & Lotus corniculatus & Vestitol & $\begin{array}{l}\text { Antisense expression of chalcone synthase } \\
(\mathrm{CHS})\end{array}$ & $\begin{array}{l}\text { Reduced vestitol accumulation in CHS antisense lines } \\
\text { (Colliver et al., 1997). }\end{array}$ \\
\hline & Medicago truncatula & $\begin{array}{l}\text { Formononetin, } \\
\text { Medicarpin }\end{array}$ & Overexpression of isoflavone synthase (IFS) & $\begin{array}{l}\text { Increased formononetin and medicarpin accumulation in } \\
\text { IFS overexpression lines (Deavours and Dixon, 2005). }\end{array}$ \\
\hline & Pisum sativum & Pisatin & $\begin{array}{l}\text { RNAi lines for }(+) 6 a-h y d r o x y m a a c k i a i n ~ 3-O- \\
\text { methyltransferase }(H M M) \text {, isoflavone } \\
\text { reductase }(I F R) \text { and sophorol reductase }(S O R) \text {. }\end{array}$ & $\begin{array}{l}\text { Reduced pisatin accumulation in } H M M, I F R \text { and } S O R \\
\text { RNAi lines (Kaimoyo and VanEtten, 2008). }\end{array}$ \\
\hline & & & $\begin{array}{l}\text { HMM antisense, overexpression of pisetin } \\
\text { demethylating activity (PDA). }\end{array}$ & $\begin{array}{l}\text { Reduced pisatin accumulation in } H M M \text { antisense and PDA } \\
\text { overexpression lines (Wu and VanEtten, 2004). }\end{array}$ \\
\hline & Oryza sativa & Sakuranetin & Overexpression of $A C D R 1$ gene. & $\begin{array}{l}\text { Increased sakuranetin accumulation and increased } \\
\text { resistance against Magnaporthe grisea in ACDR1 } \\
\text { overexpression lines (Kim et al., 2009). }\end{array}$ \\
\hline & & & Spotted leaf 18 (Spl18) mutant & $\begin{array}{l}\text { Increased sakuranetin accumulation and increased } \\
\text { resistance against Magnaporthe grisea in spl18 mutant } \\
\text { (Mori et al., 2007). }\end{array}$ \\
\hline \multirow[t]{3}{*}{ Stilbenes } & Several plant species & e.g. Resveratrol & Overexpression of STS gene & $\begin{array}{l}\text { Increased stilbene accumulation and increased resistance to } \\
\text { various pathogens in STS overexpression lines (Delaunois } \\
\text { et al., 2009; Jeandet et al., 2002). }\end{array}$ \\
\hline & Lactuca sativa & Resveratrol & Overexpression of STS & Transfer of resveratrol accumulation (Liu et al., 2006). \\
\hline & $\begin{array}{l}\text { Oryza } \quad \text { sativa, } \\
\text { Solanum } \\
\text { lycopersicum }\end{array}$ & & Overexpression of STS & $\begin{array}{l}\text { Increased resistance against Magnaporthe grisea and } \\
\text { Phytophthora infestans (Hammerschmidt, 1999). }\end{array}$ \\
\hline
\end{tabular}




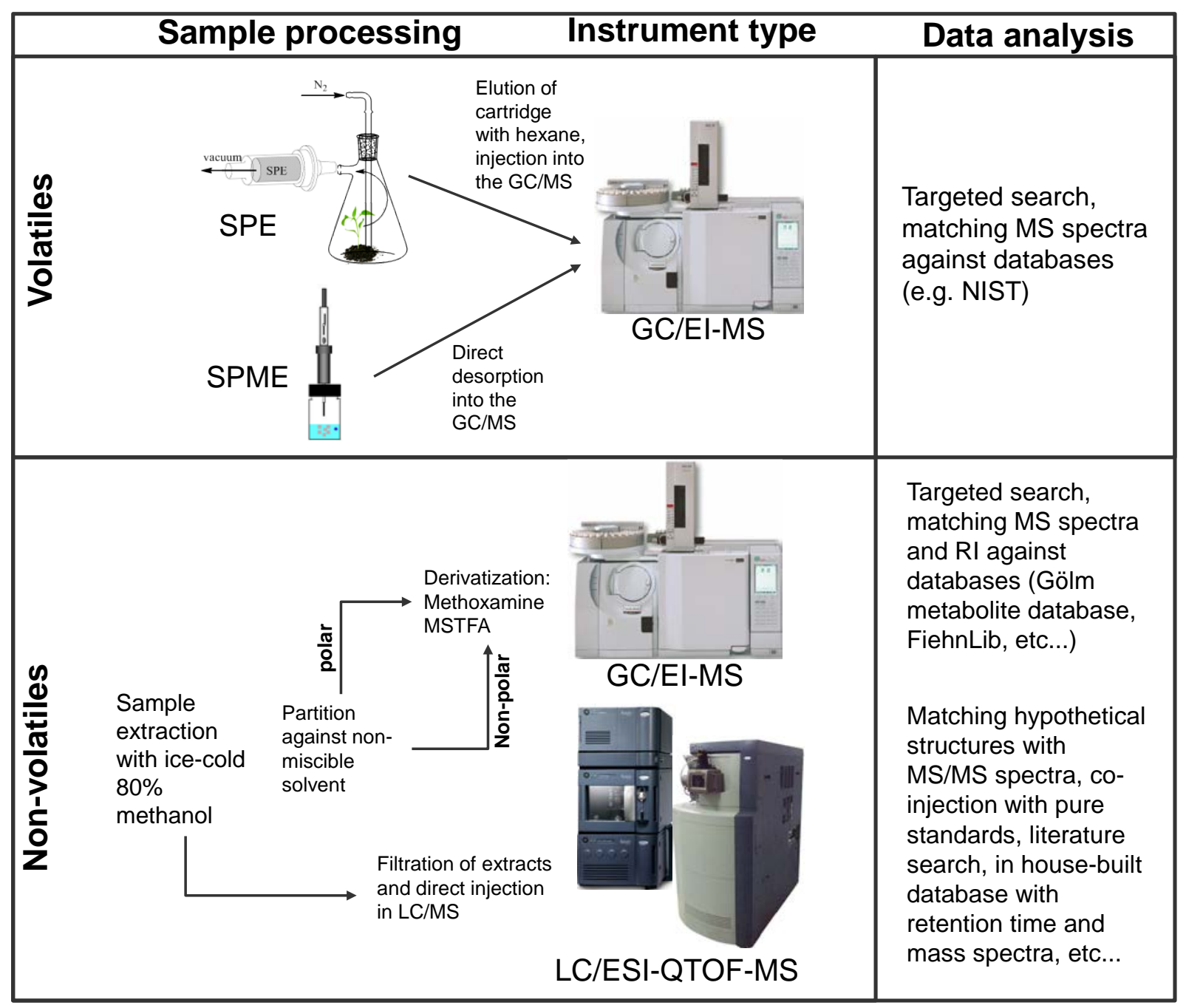

Figure 1. Diferent mass spectrometry-based metabolite profiling strategies according to sample type and metabolite class. Abbreviations: GC/EI-MS, gas chromatography/electron impact-mass spectrometry; LC/ESI-QTOF-MS, liquid chromatography/electrospray-quadrupole time-of-flight-mass spectrometry; MSTFA, methyl silyl trifluoroacetamide; SPE, solid phase extraction; SPME, solid phase microextraction. 


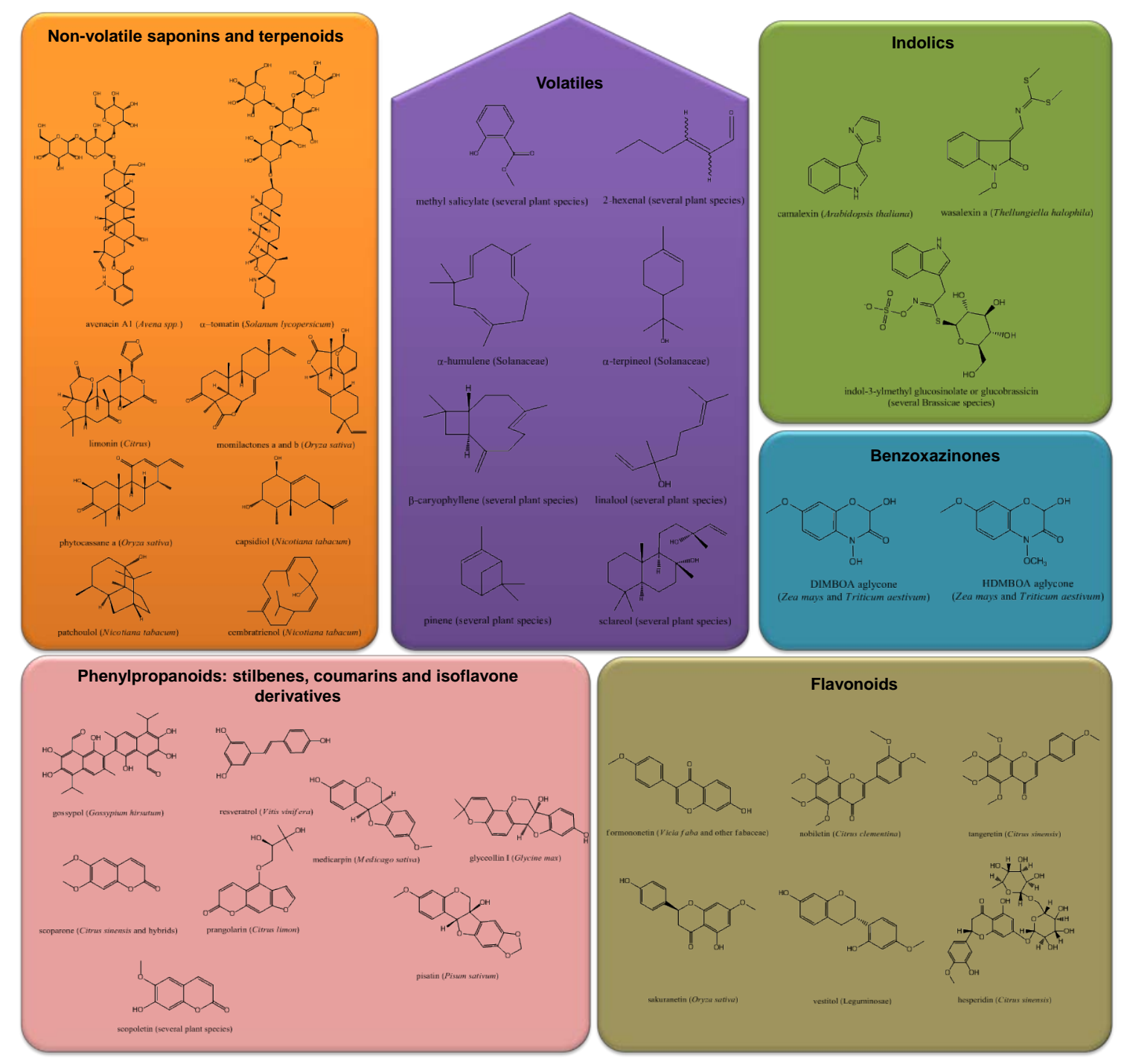

Figure 2. Compound classes and structures of metabolites involved in plant defense. 